\title{
DIVERSITY OF FLOODPLAIN FORESTS IN THE IGNEADA REGION (NW THRACE - TURKEY)
}

\author{
Ali KAVGACI ${ }^{1}$, Andraž ČARNI ${ }^{2}$, Hüseyin Bariş TECİMEN ${ }^{3}$, Gülen ÖZALP ${ }^{4}$
}

\begin{abstract}
The work deals with the floodplain forests of the Igneada region (NW Trace, Turkey). 69 relevés were sampled from wet to mesic sites according to the Braun-Blanquet approach and analyzed using different multivariate methods. The dataset was divided into five groups (associations), which demonstrate the diversity of forests in the region. In the wettest sites, forests dominated by Alnus glutinosa and Fraxinus angustifolia appear; on wet and nutrient rich sites along rivers there are forests dominated by Ulmus laevis and Fraxinus angustifolia; on wet and less nutrient rich sites Ulmus minor and Fraxinus angustifolia appear; on humid sites Fraxinus angustifolia and Carpinus betulus forests thrive and on mesic sites Carpinus betulus forests appear. The ecological conditions are estimated by bioindicator values and the gradient from wet and nutrient rich forests to mesic and nutrient poor forests is presented by numerical analysis. The species richness and geo-elemental structure for each community is evaluated. Finally, a syntaxonomical scheme is proposed and the following associations were determined Leucojo aestivi-Fraxinetum angustifoliae, Fraxino angustifoliae-Ulmetum laevis, Smilaco excelsae-Fraxinetum angustifoliae (Alno-Quercion roboris, Populetalia albae) and Geranio robertiani-Carpinetum betuli, Trachystemo orientalis-Carpinetum betuli (Castaneo-Carpinion betuli, Rhododendro pontici-Fagetalia orientalis) all within Querco-Fagetea. Key Words: azonal, flora, geoelement, gradient, nutrient, species richness, vegetation, water supply, zonal.
\end{abstract}

\section{Izvleček}

V delu obravnavamo vegetacijo poplavnih gozdov v Igneadi (SZ Trakija - Turčija). Opravili smo 69 popisov gozdov, ki se pojavljajo na mokrih, vlažnih in mezofilnih rastiščih. Gozdna vegetacija je razdeljena na pet skupin (asociacij), ki predstavljajo raznolikost teh gozdov v regiji. Na dobro namočenih rastiščih se pojavljajo gozdovi, kjer dominirata vrsti Alnus glutinosa in Fraxinus angustifolia; na mokrih in bogatih rastiščih najdemo gozdove vrst Ulmus laevis in Fraxinus angustifolia, na namočenih, vendar manj bogatih se pojavljajo gozdovi vrst Ulmus minor in Fraxinus angustifolia; na vlažnih rastiščih uspevajo gozdovi vrst Fraxinus angustifolia in Carpinus betulus, gozdovi vrste Carpinus betulus pa uspevajo na mezofilnih rastiščih. Ekološke razmere so bile opredeljene z bioindikatorskimi vrednostmi, gradient vlažnosti pa je predstavljen na podlagi numeričnih analiz. Primerjava obsega tudi bogastvo vrst različnih združb in njihovo geoelementno sestavo. Predlagana je tudi sintaskonomsko uvrstitev obravnavanih združb: Leucojo aestivi-Fraxinetum angustifoliae, Fraxino angustifoliae-Ulmetum laevis, Smilaco excelsae-Fraxinetum angustifoliae (Alno-Quercion roboris, Populetalia albae) in Geranio robertiani-Carpinetum betuli, Trachystemo orientalis-Carpinetum betuli (Castaneo-Carpinion betuli, Rhododendro pontici-Fagetalia orientalis) vse v okviru razreda Querco-Fagetea.

Ključne besede: azonalen, bogastvo vrst, flora, geoelement, gradient, hranila, vegetacija, oskrba z voda, zonalen

\footnotetext{
${ }^{1}$ Southwest Anatolia Forest Research Institute POB 26407002 Antalya - Turkey, alikavgaci1977@yahoo.com

${ }^{2}$ Institute of Biology, Scientific Research Center of the Slovenian Academy of Sciences and Arts, Novi trg 21000 Ljubljana - Slovenia and University of Nova Gorica, Nova Gorica - Slovenia, carni@zrc-sazu.si

${ }^{3}$ Istanbul University, Faculty of Forestry, Soil Science and Ecology Department 34473 Bahçeköy-Istanbul - Turkey, btecimen@istanbul.edu.tr

${ }^{4}$ Istanbul University, Faculty of Forestry, Silviculture Department, 34473 Bahçeköy-Istanbul, gulen@istanbul.edu.tr
} 


\section{INTRODUCTION}

Floodplain forests are forests in which the water table is usually at or near the surface, and the land is covered periodically or at least occasionally with shallow water (Čermák et al. 2001, Pivec 2002, Tepley et al. 2004, Paal et al. 2007). Floodplain forests have a multiple role in the landscape, since they are important from ecological, biological, environmental and economic points of view (Vukelić \& Baričević 2005, Horner et al. 2010).

The coverage of floodplain forests in $\mathrm{Eu}$ rope has decreased (Wenger et al. 1990, Glaeser \& Volk 2009) because of heavy anthropogenic pressures over centuries, including intensive cutting, construction of hydroelectric power stations and regulation of rivers (Čermák \& Prax 2001). Not only in Europe but also in other parts of the world, floodplain forests are under negative human pressure (Müller 1995, Müller 1998, Moffatt \& McLachlan 2004). This process has made floodplain forests more important in terms of ecosystem conservation than in terms of wood stock production (Jackson 1990, Tockner \& Stanford 2002). There is consequently a need to investigate these ecosystems and define their function, and it was thus highlighted that the number of studies should increase (Wenger et al. 1990). As a result of this awareness, many studies of floodplain forests have been prepared, elaborating biodiversity, function and their importance (Wildi 1989, Döring-Mederake 1990, Čermák 1998, Brullo \& Spampinato 1999, Tatarinov \& Čermák 1999, Pavlov \& Dimitrov 2002, Šilc 2002, 2003, Pietsch et al. 2003, Turner et al. 2004, Vukelić \& Baričević 2004, Drescher 2007, Franz \& Willner 2007, Willner 2007, Wallnöfer 2009, Baričević et al. 2009). Floodplain forests show rich biological and ecological diversity (Schnitzler et al. 2005) and, if they are protected, they build an important part of biological richness on a regional scale (Schuck et al. 1994). However, the floodplain forests in Europe are less biodiverse than those of America and Asia, due to the effects of the last glaciation (Schnitzler et al. 2005). From this point of view, Thrace and Anatolia perform important tasks since they hosted many species that disappeared from Europe at the time of the glaciations and found refuge here or species that settled here during the subsequent re-colonization of the Balkan Peninsula. Floodplain forests in Turkey played an important role in these processes and knowledge of them is crucial to understanding the migration of flora from the end of the Tertiary onwards (Magyari et al. 2008, Medail \& Diadema, 2009).

In the northern Turkey, there are several riverine and floodplain forests, some of which have already been studied in terms of ecology and biology (Pamay 1967, Kutbay et al. 1998, Çiçek 2002, Çakır et al. 2007, Başkent et al. 2008).

Our research took place in floodplain forest in NW Turkey, in the well-known Igneada Region, one of the important plant areas in Turkey (Özhatay et al. 2003). Its biological richness has already been elaborated (Kavgacı 2007, Kavgacı et al. 2007, Tecimen \& Kavgacı 2010, Kavgacı et al. 2010) and two EU supported projects have taken place there: GEF II and Yildız Dagları (Istranca) Mountains Biogenetic Reserve project.

Since the vegetation of the area has not yet been investigated, the main goal of this work was to present the floristic composition of the communities and the ecological conditions. We attempted to detect the main gradients and characteristics within these forests. At the same time, we tried to place these forests in a broader context as transitional types between the Balkans and Anatolia.

\section{MATERIALS AND METHODS}

\subsection{Study Area}

The study area is situated in NW Thrace, which is composed of a mountainous part and lowland (Figure 1). The Ylldiz (Istranca) mountain range is parallel to the coastline and, at its foot is situated Igneada region, which is covered by floodplain forests (Kantarc1 1976). In addition to the floodplain forests called Saka, Mert and Erikli, there are also lakes, swamps, scrub communities and sand dunes (Özhatay et al. 2003, Kavgacı 2007).

The average annual rainfall is about $800 \mathrm{~mm}$ and the average temperature is $13^{\circ} \mathrm{C}$. The hottest month is August and the coldest month is February (Anon. 2006). According to the Thornthwaite (1948) climate system, the research area has a humid and mesothermal sea climate. The bedrock is mainly formed by sedimentary rocks, including alluvial, calcareous rocks, non-calcareous and pliocene sedimentary rocks, dunes and siltstone flysch-schists (Kantarc1 1979, Sevgi 2005). 


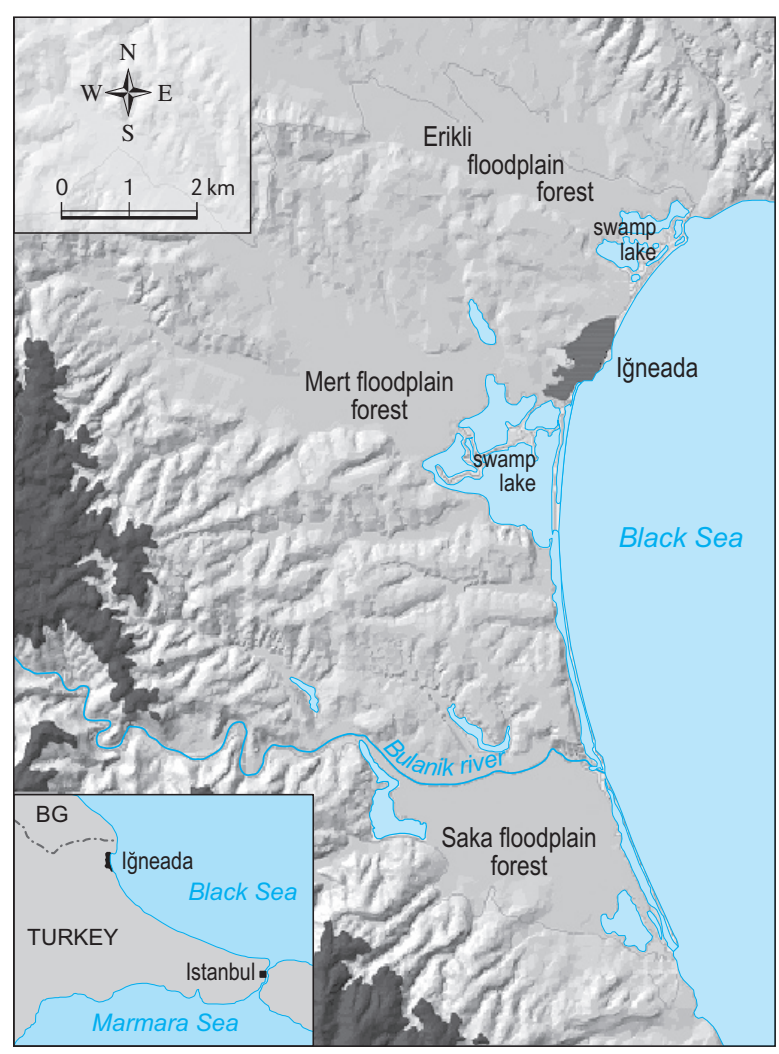

Figure 1: Geographical position of the study area. Slika 1: Geografski položaj raziskovanega območja.

\subsection{Analysis of Vegetation Data}

The field work was carried out between 2003 and 2006. We sampled floodplain forests dominated by Fraxinus angustifolia, Alnus glutinosa, Carpinus betulus, Ulmus minor, U. leavis, Acer campestre, A. trautwetteri, Fuglans regia and Quercus robur. In addition to all types of floodplain forests, we included in our analysis seasonally dry riverine forest with Carpinus betulus, Fagus orientalis, Populus tremula and Tilia argentea. We chose homogenous sampling plots with an area of $400 \mathrm{~m}^{2}$. The protocol for each plot includes general, topographic and other data of individual plots, such as altitude, inclination, aspect, vegetation cover (total and of individual layers) and a list of all vascular plants, in which a cover value was assigned to each species according to the nine degree BraunBlanquet scale (Braun-Blanquet 1964, Westhoff $\&$ van der Maarel 1973).

The samples (hereinafter relevés) were stored in the TURBOVEG database management program (Hennekens \& Schaminée 2001). Hierarchical classification of the data set was carried out in the computer program PC-ORD (Mc Cune \& Meffords 2003). The Jaccard coefficient was used as a resemblance measure for analysis and the beta-flexible algorithm with $ß:-0.25$ for the construction of the dendrogram construction. Various levels of division were accepted in the dendrogram, resulting in six clusters interpretable in terms of ecology. Additionally, the diagnostic species of the accepted clusters were identified by a fidelity measure in the JUICE program (Tichý 2002). The threshold of the phi value was subjectively selected at 0.50 for a species to be considered as diagnostic (Chytrý et al. 2002).

The results of the classification were visualized by ordination techniques in the CANOCO 4.5 package (ter Braak \& Šmilauer 2002). Detrended Canonical Analysis (DCA), which is an indirect ordination method assuming a unimodal response of species to the environment, was run due to the high heterogeneity in the matrix of species (Lepš \& Šmilauer 2003).

Unweighted average indicator values (Pignatti 2005) were used for further interpretation of ecological conditions (Zelnik \& Čarni, 2008). Although the bio-indicator values were selected for Italy, they are useful and often used also for Balkan and Thracian vegetation (Kavgaci 2007, Tsiripidis et al. 2007, Košir et al. 2008, Kavgacı et al. 2010). They were passively projected on an ordination plane. Moreover, the comparison of ecological conditions in the six clusters was visualized by a Box-Wisherkers diagram prepared in STATISTICA 8.0 (Anon. 2007). We also calculated the spectra of geo-elements according to Davis (1965-1985) and Davis et al. (1988) and also projected the most abundant groups of geo-elements (widely-distributed, euro-siberian and mediterranean species) passively on the ordination plane.

The nomenclature of plant species follows Flora of Turkey (Davis 1965-1985, Davis et al. 1988) and new syntaxa were described in accordance with the International Code of Phytosociological Nomenclature (Weber et al. 2000).

\section{RESULTS}

\subsection{Classification}

The classification of relevés from Table 1 shows five main clusters (Figure 2). The comparison of bioindicator values for each cluster is shown in Figure 3. 


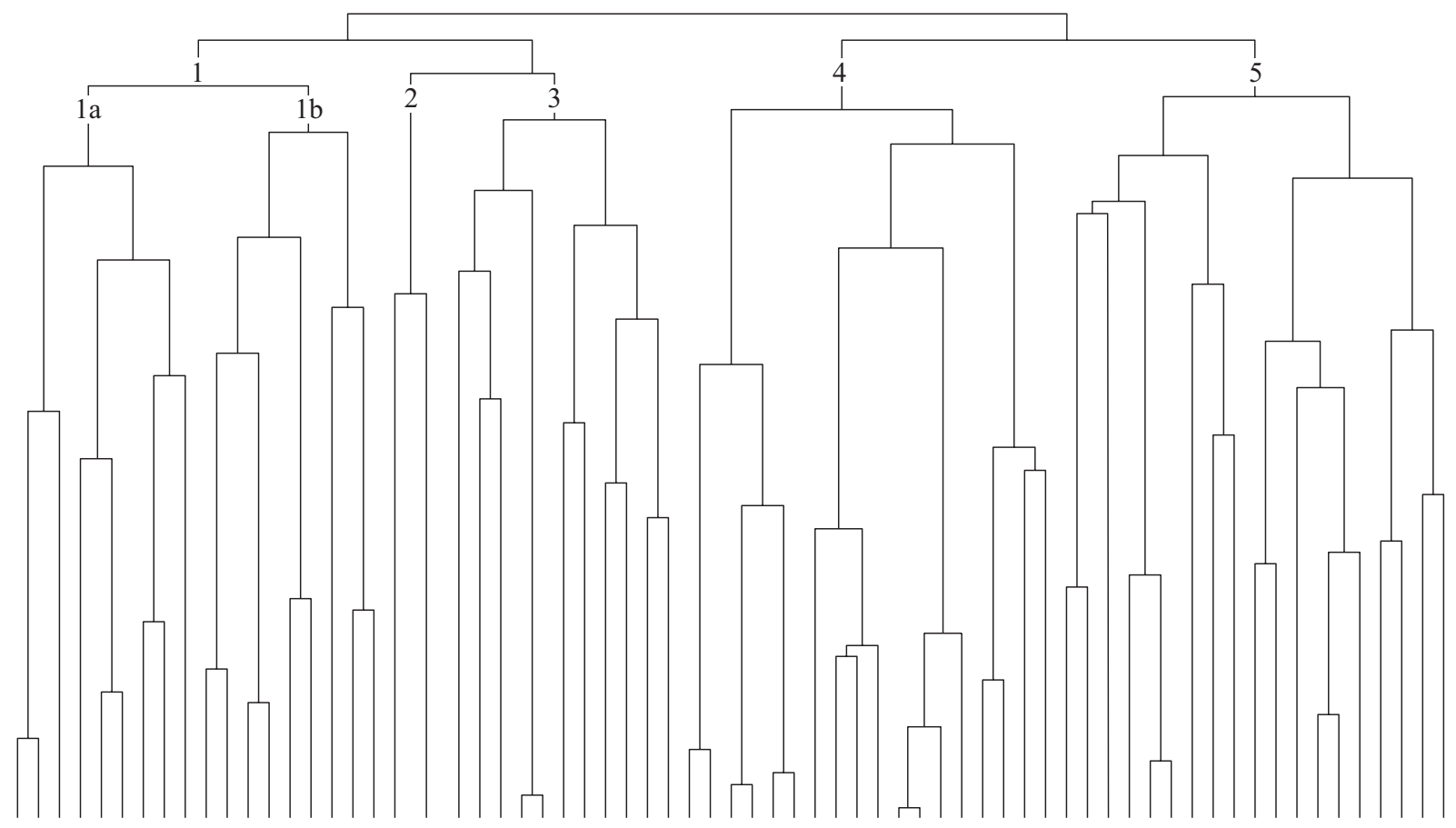

Figure 2: Hierarchical classification diagram of relevés of floodplain forests. Numbers correspond to the communities: 1. Ulmus laevis-Fraxinus angustifolia dominated forest, 1a. typical sub-community, 1b. Juglans regia sub-community, 2. Alnus glutinosa-Fraxinus angustifolia dominated forest, 3. Ulmus minor-Fraxinus angustifolia dominated forest, 4. Carpinus betulus-Fraxinus angustifolia dominated forest, 5. Carpinus betulus dominated forest.

Slika 2: Graf hierarhične klasifikacije popisov poplavnih gozdov. Številke prikazujejo združbe: 1. gozd, kjer prevladujeta Ulmus laevis-Fraxinus angustifolia, 1a. tipična podzdružba, 1b. Juglans regia podzdružba, 2. gozd, kjer prevladujeta Alnus glutinosa-Fraxinus angustifolia, 3. gozd, kjer prevladujeta Ulmus minor-Fraxinus angustifolia, 4. gozd, kjer prevladujeta Carpinus betulus-Fraxinus angustifolia, 5. gozd, kjer prevladuje Carpinus betulus.

Cluster 1 includes Ulmus laevis-Fraxinus angustifolia dominated forests. The diagnostic species are: Acer trautvetteri, Circaea lutetiana, Chaerophyllum temulum, Fuglans regia, Parietaria officinalis, Phytolacca americana, Sambucus nigra, Ulmus laevis and Urtica dioica. It is formed by two different subcommunities, one of which is typical, specified by the absence of any diagnostic species and the other is a fuglans regia subcommunity, characterized by Acer trautvetteri, Chaerophyllum temulum, fuglans regia, Parietaria officinalis, Phytolacca americana and Sambucus nigra. Alnus glutinosa and Acer campestre can sporadically appear in this community. Tree layer of this forest is composed by more than two strata (multi-cohort stand structure). The upper tree layer reaches more than $30 \mathrm{~m}$ and the stands are located in the Saka Floodplain Forest.

Cluster 2 represents Alnus glutinosa-Fraxinus angustifolia dominated forests. The diagnostic species of the community are Alnus glutinosa, Fraxinus angustifolia, Galium debile, Iris pseudacorus, Leucojum aestivum, Lysimachia vulgaris and Polygonum lapathifolium. This community, characterised by a single cohort coppice stand structure, is also located in Saka Floodplain Forest in a very limited distribution zone within the lake.

Cluster 3 represents Ulmus minor-Fraxinus angustifolia dominated forests. The diagnostic species of the community are Lysimachia nummularia, Ranunculus repens, Ulmus minor and Veronica serpyllifolia. The tree species mixture of the community is locally enriched by Acer campestre, Carpinus betulus and Quercus robur. This forest also reflects a multi-cohort stand structure, with a stand height of more than $30 \mathrm{~m}$. In contrast to the former communities, this community is fully distributed in the Mert and Erikli Floodplain Forests, which may indicate ecological and floristical differences among the floodplain forests in the region.

Cluster 4 includes Carpinus betulus-Fraxinus angustifolia dominated forests. The diagnostic species of the community are Acer campestre, Carpinus betulus, Geranium robertianum, Mercurialis perennis, Polygonatum lapatifolium. This community, which is 
mostly located in Mert and Erikli Floodplain Forests, also displays a multi-cohort stand structure, with a stand height of more than $30 \mathrm{~m}$. The lower tree layer of the community is mainly formed by Carpinus betulus coppice. Other tree species found locally in the stand mixture are Quercus robur and Ulmus minor, which appears in the lower tree layer.

Cluster 5 represents forests mainly formed by Carpinus betulus. This forest is the most distant from the river and the moisture and nutrient values are the lowest (Figure 3). This community consists of more diagnostic species than the former communities: Carpinus betulus, Epimedium pubigerum, Fagus orientalis, Fragaria vesca, Galium paschale, Lathyrus laxiflorus, Populus tremula, Primula vulgaris, Pteridium aquilinum, Quercus petraea, Tilia argentea, Trachystemon orientalis and Veronica chamaedrys. Carpinus betulus dominated forests taking place on the seasonally dry river beds covered by thermophilous mixed oak forests. These forests therefore locally contain some thermophilous oak species, such as Quercus frainetto, $Q$. petraea and Q. cerris. Additionally, Carpinus betulus densely appears on gently inclined slopes surrounding the floodplains. Fagus orientalis, which is densely distributed in the lower montane altitudinal belt in the region, join the floristic composition. Populus tremula, a pioneer species locally forms pure groups in this community. Due to the high proportion of shade tolerant species in the tree composition, this community has a multi-cohort coppice forest structure, with an upper tree height of about $25 \mathrm{~m}$. As the floristic and ecological structure of this forest is observed, we can easily recognize its mesophilous characters.

\subsection{Ordination and Comparison of Bioindicator Values and Geo- ELEMENTAL STRUCTURE}

The ordination of the relevés using DCA presents a clear gradient along the axes 1 (Figure 3) showing ecological differences among the floodplain forest communities. As can be seen, moisture and nutrient are strictly correlated with axis 1 . Other variables have less importance on this axis. Moisture and nutrient appear as the main determinant environmental factors for the communities in the floodplain forests. The clear gradient of these environmental factors can also be seen in Figure 4, corresponding to the geo-elemental structure (Figure 3).

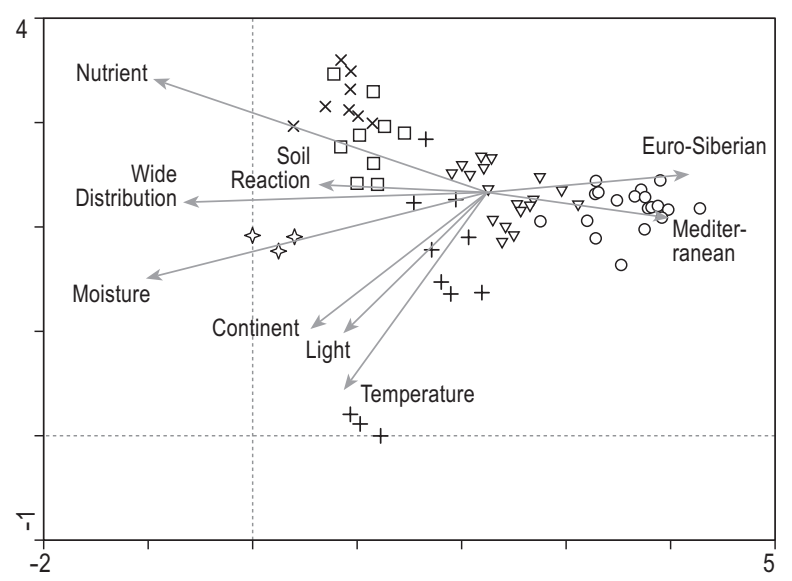

Figure 3: DCA ordination of relevés with the passive projection of bioindicator value and geo-elemental structure, $\square$ : Ulmus laevis-Fraxinus angustifolia dominated forest (typical sub-community), $\times$ : Ulmus laevis-Fraxinus angustifolia dominated forest (Juglans regia sub-community), ↔: Alnus glutinosa-Fraxinus angustifolia dominated forest, +: Ulmus minor-Fraxinus angustifolia dominated forest, $\nabla$ : Carpinus betulus-Fraxinus angustifolia dominated forest, ○: Carpinus betulus dominated forest.

Slika 3: DCA ordinacija popisov s pasivno projeciranimi bioindikatorskimi vrednostmi in deležem pripadnosti fitogeografskim regijam, $\square$ : gozd, kjer prevladujeta Ulmus laevis-Fraxinus angustifolia (tipična podzdružba), x: gozd, kjer prevladujeta Ulmus laevis-Fraxinus angustifolia (Juglans regia podzdružba), §: gozd, kjer prevladujeta Alnus glutinosa-Fraxinus angustifolia, +: gozd, kjer prevladujeta Ulmus minor-Fraxinus angustifolia, $\nabla$ : gozd, kjer prevladujeta Carpinus betulus-Fraxinus angustifolia, ○: gozd, kjer prevladuje Carpinus betulus.

As can be seen, stands of Alnus glutinosa-Fraxinus angustifolia dominated forests appear on the wettest parts of the floodplains (Figure 3). These communities are also the species poorest (Figure 5) and are dominated by widely distributed wetland species showing the extreme ecological conditions (Figure 4).

The Ulmus laevis-Fraxinus angustifolia dominated forest type is also found on nutrient rich sites of the floodplains with high water saturation (Figure 3,4$)$. Within this forest, the fuglans regia subcommunity is more characteristic of nutrient rich sites than the typical sub-community.

According to the nutrient and moisture content of the soils the Ulmus minor-Fraxinus angustifolia dominated forest type reflects the intermediate level of floodplain forests in the region (Figure 4).

Although Carpinus betulus-Fraxinus angustifolia dominated forest reflects the poorer nutrient and 

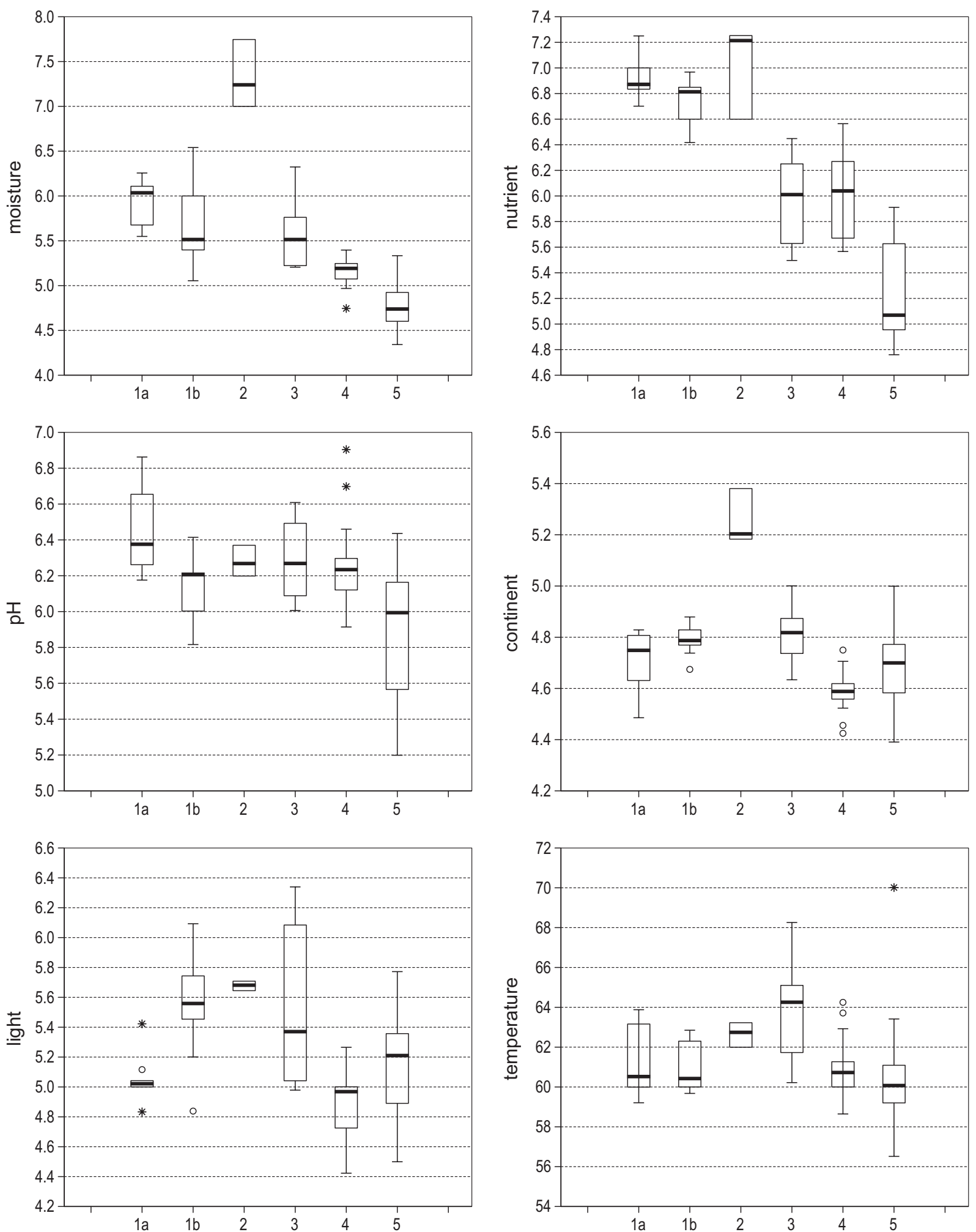

Figure 4: Diagrams of bioindicator values for each community. Numbers correspond to the community number in Figure 2. — : Median, $\square: 25 \%-75 \%$, I: Non-outlier range, o: outliers, * : extremes.

Slika 4: Graf bioindikatorskih vrednosti za posamezne združbe. Številke prikazujejo združbe kot v Sliki 2. — : Mediana, $\square: 25 \%-75 \%$, I : razpon brez osamelcev, o: osamelci, * : ekstremi. 
moisture parts of the woodland compared with the formers, the sites of this community show a higher nutrient contents and a better water supply than Carpinus betulus dominated forests (Figure 4).

The nutrient and moisture poorest parts of floodplain forest are characterized by Carpinus betulus dominated forests, which appear on seasonally dry rivers that are covered with water only in winter. The latter two forests have closed canopy and light availability is the lowest. The same also applies for temperature, which indicates that a special, more mesophilous microclimate appears in these forests (Figure 3). At the same time, it is noticeable that the proportion of euro-siberian and mediterranean species is here the highest. (Figure 3)

The DCA ordination also shows a gradient along the Axis 2. However, as seen, it is mostly related to some relevés of Ulmus minor-Fraxinus angustifolia dominated forests. These are comparably as wet as Ulmus laevis-Fraxinus angustifolia forests, but possess a lower nutrient status. Higher temperature and light bioindicator values show that the canopy is not closed and species indicate trampling and grazing in these forests, such as Lysimachia nummularia, Ranunculus repens and Veronica serpyllifolia, which are also diagnostic for the community (Figure 3,4).

According to the phytogeographical structures of the communities (Figure 3), it can be seen that the communities on more humid sites are mainly formed by widely distributed species. In contrast, in communities appearing on drier sites the floristic composition is dominated by euro-siberian and mediterranean species.

Floodplain forests in the region reflect various species richness (Figure 5). Species richness is low in Alnus glutinosa-Fraxinus angustifolia dominated forests, and is high in the Carpinus betulus dominated forest. There is a clear gradient of species richness from humid to drier sites.

\section{DISCUSSION}

Floodplain forests in the Igneada region (NW Thrace - Turkey) show clear differences in terms of ecological conditions. Nutrient and moisture are the most important ecological factors determining the distribution of floodplain forest communities in the region. On the basis of moisture and soil nutrient content, these forests indicate significant differences, although all of them contain

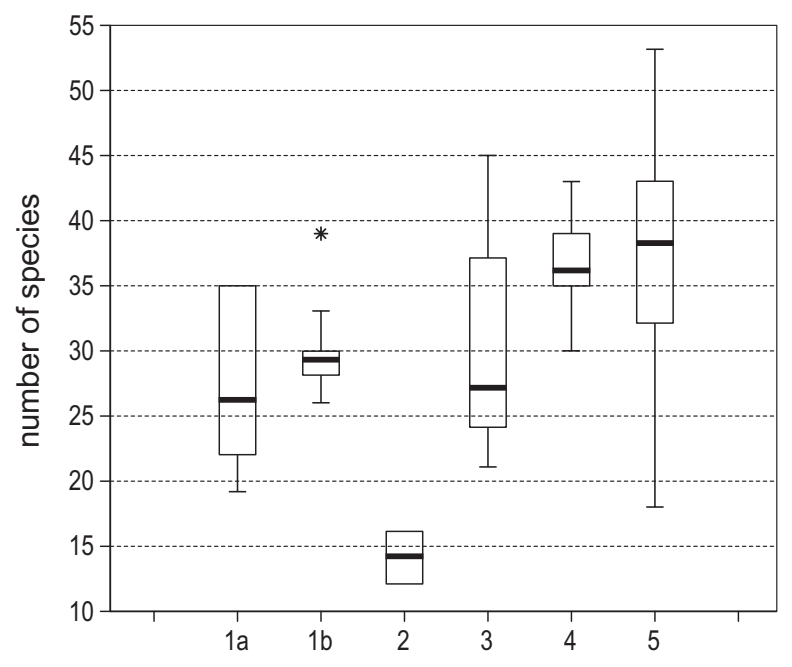

Figure 5: Species richness of the communities. Numbers correspond to the community numbers in Figure 2. - : Median, $\square$ : 25\%-75\%, I : Non-outlier range, o: outliers, *: extremes.

Slike 5: Vrstna pestrost združb. Species richness of the communities. Številke prikazujejo združbe kot v Sliki 2. - : Mediana, $\square: 25 \%-75 \%$, I : razpon brez osamelcev, o: osamelci, *: ekstremi.

more nutrient and moisture in their sites than the thermophilous oak forests (Kavgacı et al. 2010) surrounding the floodplains. It is assumed that these differences are a result of the physiography and the flooding regime, which has an identifiable impact on the floristic composition of the communities and abundance of trees (Monica et al. 2004).

Alnus glutinosa-Fraxinus angustifolia dominated forest is located in the most humid part of the region. These stands are dominated by Fraxinus angustifolia, but sites that are in depressions and flooded or even submerged throughout the year are dominated by Alnus glutinosa, which best supports such conditions. (Kramer et al. 2008, Douda et al. 2009). The community is similar to the community found in Middle and Eastern Europe and these forests can therefore be classified as Leucojo-Fraxinetum angustifoliae Glavač 1959 alnetosum Glavač 1959. Similar stands appear also in the Greek part of Trace. These forests are mediating with the marshy forest of the class Alnetea glutinosae and some author classify them within this class (Glavač 1959, Zoller et al. 1977, Raus 1980, Baričević 1998, Brullo \& Spampinato 1999, Vukelić \& Baričević 2005).

Ulmus laevis-Fraxinus angustifolia forests can be found in sites with high soil moisture, distrib- 
uted near the largest river in the region (Bulanık River). During the summer they have the typical appearance of floodplain forests, containing numerous nitrophilous tall herbs, above all Urtica dioica, which builds with its rhizomes dense, impassable stands, but also Chaerophyllum temulum, Parietaria officinalis and other plants that show that nutrients are brought regularly into the stands. These communities can be classified into Fraxino angustifoliae-Ulmetum laevis Slavnić 1952, which are reported from the northern part of the Balkans, along the Danube River (Slavnić 1952, Vukelić \& Baričević 2005, Čarni et al. 2008). The association can be divided into two sub-associations, one typicum, representing the average site conditions and sub-association juglandetosum subass. nova, thriving on nutrient richer sites and characterized by Acer trautvetteri, Chaerophyllum temulum, Fuglans regia, Parietaria officinalis, Phytolacca americana and Sambucus nigra. The holotype of the subassociation is relevé number 10 in Table 1 (holotypus: Tab.1/10 holotypus hoc loco).

Although the habitat preference of Ulmus laevis is riparian woodlands, Ulmus minor can also be found in woodlands and it is also widely planted (Eriksson 2001). Ulmus minor-Fraxinus angustifolia dominated forest can be found in humid habitats that are distant from the river and therefore nutrient poorer. These habitats with small brooks and soaked with trickling water that is partially also stagnant are still humid.

The floristic and ecological structure of Ulmus minor-Fraxinus angustifolia dominated forest corresponds to floodplain forests in the Dolna Topchiya and Balabana reserves in Bulgaria. Similar forests have been found northern Greece and the name Periploco-Ulmetum was proposed for them. (Zoller et al. 1977) Zoller et al. (1977) even mentioned that similar stands can be found in eastern and northeastern Bulgaria. Later on such forests have been classified as Smilaco excelsae-Fraxinetum angustifoliae Pavlov and Dimitrov 2002 (Pavlov \& Dimitrov 2002). Even the subassociation, prunelletosum vulgaris Pavlov and Dimitrov 2002 was described, which can accommodate our community. It is characterized by Ranunculus repens, Lysimachia nummularia and Veronica sepyllifolia. These are species of trampled habitats, often found on forest roads (Čarni 2005), which indicates degraded forest. Forest grazing is also widely practiced in these woodlands.

Floodplain forests are an azonal type of deciduous forests in the temperate zone (Klimo \&
Herbert 2001) and they are mainly formed by species with a wide distribution. Because of that, the floodplain forests in the region appearing on more humid sites are characterised by a higher presence of widely distributed species, whereas euro-siberian and mediterranean species appear higher in drier soils. They can be treated as azonal since they are strongly influenced by soil features and climate has only a minor influence (Breckle 2002). Additionally, there is a negative correlation between soil nutrient content and species richness (Huston 1980). There is therefore higher species richness in drier and nutrient poorer Fraxinus angustifolia-Carpinus betulus dominated and Carpinus betulus dominated forests, which can be treated as zonal vegetation of the region.

Fraxinus angustifolia-Carpinus betulus dominated forests and Carpinus betulus dominated forests in the study area can be found in the drier parts of the region. Carpinus betulus is less competitive on very moist to wet sites. (Baričević 1998, Kramer et al. 2008). Drier sites are covered by Carpinus betulus dominated forests. Communities indicate similar differences in terms of the nutrient content of the sites as with moisture content. Turner et al. (2004) obtained similar results in floodplain forests, finding that flood-tolerant and flood-intolerant species were grouped separately in floodplain forests. In the study area, these communities have a floristic composition formed mainly by the flora of broadleaved forests appearing on drier conditions. These are zonal forests, characterized by mesophilous species that reflect the local climatical and the geomorphological position. This is the area of distribution of the order Rhododendro pontici-Fagetalia orientalis (Horvat et al. 1974, Akman 1995, Tzonev et al. 2006, Aydin et al. 2008), which is reflected in the floristic composition of the communities.

The classification into alliances is not so evident, since Carpinus betulus dominated forests from the European part of Turkey have not been classified on an alliance level. The Carpinus betulus dominated forest in Belgrad Forests in Northern Istanbul, called "Carpinus betulus-Acer campestre association" was only classified under Rhododendro-Fagetalia (Yaltırık et al. 1983), without being assigned to any alliances of this order. Similarly, in another work carried out by Kılınç and Karaer (1995) in the lowland of Black Sea Region, the forests dominated by Carpinus betulus, and also by Fagus orientalis, were classified under Rhodo- 
dendro-Fagetalia but were not defined on an alliance level. The reason could be the description of alliances of Rhododendro-Fagetalia proposed by Quézel et al. (1980). They described the alliance dominated by Carpinus betulus in the eastern part of the Turkish Black Sea coast and therefore the character species do not match with those from the western part. Nevertheless, it was decided to classify the communities under consideration into the alliance Castaneo-Carpinion Quézel et al. 1980, because ecologically and phytogeographically they match the alliance, which includes euxine mixed broad leaved forests with Castanea, Carpinus, Tilia and Fagus on humid slopes and in ravines (Aydin et al. 2008). In the future, more material should be collected and a synthetic overview of these forests is needed to (re)define the characteristic species and to show their relations with other Carpinus betulus dominated forest of the alliance Erythronio-Carpinion (Fagetalia sylvaticae) found in SE Europe (Marinček \& Čarni 2000) and with other alliances of RhododendroFagetalia occuring in the region. Carpinus betulus forests in Turkey can also be classified into the alliance Aceri-Carpinion Quézel et al. 1980, but these communities are more thermophilous and are included in Quercetea pubescentis (Quézel et al. 1980, Türe et al. 2005), which are not treated in this paper.

Since there is no association that would accommodate Fraxinus angustifolia-Carpinus betulus dominated and C. betulus dominated forest, it was necessary to describe a new associations.

It was decided to classify Fraxino angustifoliaeCarpinus betulus forest as Geranio robertiani-Carpinetum betuli ass. nova hoc loco. The nomenclatural type is relevé number 39 in Table 1 (holotypus hoc loco: Tab. 1/39). The association is found on more humid sites than Carpinus betulus dominated forests (i.e., Trachystemo-Carpinetum) and is close to Smilaco excelsae-Fraxinetum angustifoliae. These forests are distributed in the area of distribution of the order Rhododendro-Fagetalia. The diagnostic species combination is: Acer campestre, Carpinus betulus, Corylus avellana, Crataegus monogyna, Fraxinus angustifolia, Hedera helix, Carex remota, Carex sylvatica, Carpinus betulus, Circaea lutetiana, Dactylis glomerata, Geranium robertianum, Geum urbanum, Lamium maculatum, Mercurialis perennis, Mycelis muralis, Polygonum lapatifolium, Rumex conglomeratus, Ruscus aculeatus, Smilax excelsa, Viola alba, Viola sieheana. The Quercus robur dominated forests in the floodplain forests of NW Thrace was classified within the broader syntaxon Carici-Fraxinetum (Kavgacı et. al 2010), but the present analysis on finer scale shows that the relevés formerly classified into Carici-Fraxinetum should be desintegrated and classified into Geranio robertiani-Carpinetum betuli and Smilaco excelsae-Fraxinetum angustifoliae. The distribution of Carpinus betulus in the forest of Igneada is relatively larger that it would be according to the site conditions. This could be a result of legal and illegal cuttings that were carried out in the past and especially focused on valuable stems of Fraxinus angustifolia and Quercus robur.

Carpinus betulus dominated forests are classified within the Trachystemo orientalis-Carpinetum betuli ass. nova hoc loco. The nomenclatural type is relevé 65 in Table 1. (holotypus hoc loco: Tab. $1 / 65)$. The association is represented by well developed, mesophilous Carpinus betulus dominated forests in seasonally dry riverbeds. The diagnostic species combination is: Ajuga reptans, Carpinus betulus, Carex sylvatica, Epimedium pubigerum, Fagus orientalis, Fragaria vesca, Galium paschale, Hedera helix, Lathyrus laxiflorus, Mycelis muralis, Populus tremula, Primula vulgaris, Quercus petraea, Ruscus aculeatus, Smilax excelsa,Tilia argentea, Trachystemon orientalis, Viola alba, Viola sieheana.

According to these syntaxonomical assessments, a syntaxanomical overview of floodplain forests in NW Thrace is as follows:

\section{Querco-Fagetea Br.-Bl. et Vlieger 1937}

Populetalia alba Br.-Bl. ex Tchou 1948 Alno-Quercion roboris Horvat 1950

Leucojo aestivi-Fraxinetum angustifoliae Glavač 1959 alnetosum glutinosae Glavač 1959

Fraxino angustifoliae-Ulmetum laevis Slavić 1952

juglandetosum typicum regiae Kavgacı et al. subass. nova

Smilaco excelsae-Fraxinetum angustifoliae Pavlov et Dimitrov 2002 prunelletosum vulgaris Pavlov et Dimitrov 2002

Rhododendro pontici-Fagetalia orientalis Quézel, Barbéro et Akman 1980

Castaneo-Carpinion Quézel, Barbéro et Akman 1980

Geranio robertiani-Carpinetum betuli Kavgacı et al. ass. nova

Trachystemo orientalis-Carpinetum betuli Kavgacı et al. ass. nova 


\section{ACKNOWLEDGEMENTS}

The authors acknowledge the financial support of the TUBITAK project (TOVAG 3313) and various projects of the Slovenian Research Agency (project No. L1-9737 and P1-0236). We would also like to thank the Forestry Faculty of Istanbul University, Southwest Anatolia Forest Research Institute and Scientific Research Center of the Slovenian Academy of Sciences and Arts for logistic supports. We also thank two anonymous reviewers for their kind comments and suggestions.

\section{REFERENCES}

Akman, Y. 1995: Türkiye Orman Vejetasyonu. Ankara Üniversitesi Fen Fakültesi, Ankara.

Anon., 2006: The data of Kumkoy Meteoroloji Station. Istanbul.

Anon., 2007: STATISTICA (data analysis software system). Version 8.0. StatSoft, Inc., www. statsoft.com

Aydın, C.T., Bergmeier, E., \& Walentowski, H. 2008: Vegetation und Standort in der Waldlandschaft der Nordwest Türkei. Önel Druck \&Verlag, Köln.

Baričević, D. 1998: Ecological-Vegetational properties of Forest Žutica. Glas. Sum. Pokuse 35: 1-91

Baričević, D., Pernar, N., Vukelić, J., Mikac, S. \& Bakšić, D. 2009: Floristic composition as an indicator of destabilisation of lowland forest ecosystems in Posavina. Periodicum Biologorum 111(4): 443-451.

Başkent, E. Z., Terzioğlu, S. \& Başkaya, Ş. 2008: Developing and implementing multiple-use forest management planning in Turkey. Environmental Management, 42:37-48.

Braun-Blanquet, J. 1964: Pflanzensoziologie. Grundzüge der Vegetationskunde. $3^{\text {rd }}$ ed. Springer, Wien.

Breckle, S.W. 2002: Walter vegetation of the Earth. The ecological system of the geo-biosphere. $4^{\text {th }}$ edition. Springer Verlag, Berlin.

Brullo, S. \& Spampinato, G. 1999: Syntaxonomy of hygrophilous woods of the Alno-Quercion roboris. Annali di Botanica 57: 133-146.

Čarni, A. 2005: Vegetation of trampled habitats in the Prekmurje region (NE Slovenia). Hacquetia 4: 151-159.

Čarni A., Košir, P., Marinček, L., Marinšek, A., Šilc, U. \& Zelnik, I. 2008: Komentar k vege- tacijski karti gozdnih združb Slovenije v merilu 1:50.000 - list Murska Sobota. PAZU, Murska Sobota.

Čermák, J. 1998: Leaf distribution in large trees and stands of the floodplain forest in southern Moravia. Tree Physiology 18: 727-737.

Čermák, J. Kučera, J., Prax, A., Bednářová, F. T. \& Nadyezhdin, V. 2001: Long-term course of transpiration in a floodplain forest in southern Moravia associated with changes of underground water table. Ekológia 20: 92-115.

Čermák, J. \& Prax, A. 2001: Water balance of a Southern Moravian floodplain forest under natural and modified soil water regimes and its ecological consequences. Ann. For. Sci. 58: $15-29$.

Chytrý, M., Tichý, L., Holt, J. \& Botta-Dukát, Z. 2002: Determination of diagnostic species with statistical fidelity measures. Journal of Vegetation Science 13: 79-90.

Çakır, G., Sivrikaya, F., Terzioğlu, S., Başkent, E. Z., Sönmez, T. \& Yolasığmaz, H. A., 2007: Mapping secondary forest succesion with geographical information systems: A case study from Bulanıkdere, Kırklareli, Turkey. Turk. J. Agric. 31: 71-81.

Çiçek, E. 2002: Adapazarı-Süleymaniye Subasar Ormanında Meşcere Kuruluşları ve Gerekli Silvikültürel Önlemler, PhD Thesis, İstanbul Üniversitesi Fen Bilimleri Enstitüsü, 138 pp.

Davis, P. H. 1965-1985: Flora of Turkey and the East Aegean Islands. Vol. 1-9, Edinburgh Univ. Press, Edinburgh.

Davis, P. H., Mill, R. R. \& Tan, K. 1988: Flora of Turkey and the East Aegean Islands. Vol. 10, Edinburgh Univ. Press, Edinburgh.

Drescher, A. 2007: Ulmenion Oberd. 1953. In: Willner, W. \& Grabherr, G. (eds.) 2007. Die Wälder und Gebüsche Österreichs. Elsevier Verlag. München, p. 123-127.

Douda, J., Čejková, Douda, K. \& Kochánková J. 2009: Development of alder carr after abandonment of wet grasslands during the last 70 years. Annals of forest science 66(7) 10.1051/ forest/2009065.

Döring-Mederake, U. 1990: Alnion forests in lower Saxony (FRG), their ecological requirements, classification and position within Carici elongatae-Alnetum of Northern Central Europe. Vegetatio 89: 107-119.

Eriksson, G., 2001: Conservation of noble hardwoods in Europe. Canadian Journal of Forest Research 31: 577-587. 
Franz, W.R. \& Willner, W. 2007: Somergrüne Laubwälder. In: Willner, W. \& Grabherr, G. (eds.): Die Wälder und Gebüsche Österreichs. Elsevier Verlag. München, p. 89-93.

Glaeser, J. \& Volk, H. 2009: The historical development of floodplain forests in Germany - a review. Allgemaine Forsts- und Jagdzeitung 180: 140-151.

Glavač, V. 1959: O šumi poljskog jasena s kasnim drijemovcem. Šum. list 83 (1-3): 39-45.

Hennekens, S. M. \& Schaminée, J. H. J. 2001: TURBOVEG a comprehensive data base management system for vegetation data. Journal of Vegetation Science 12: 589-591.

Horner G.J., Baker P.J., Mac Nally, R., Cunningham, S.C. Thomson, J.R. \& Hamilton, F. 2010: Forest structure, habitat and carbon benefits from thinning floodplain forests: Managing early stand density makes a difference. Forest ecology and management 259: 286-293.

Horvat, I., Glavač, V. \& Ellenberg, H. 1974: Vegetation Südosteuropas, Gustav Fischer Verlag, Stuttgart.

Huston, M. 1980: Soil nutrient and tree species richness in Costa Rican Forests. Journal of Biogeography 7: 147-157.

Jackson, B. D. 1990: Identification and Inventory of the International Forested - Wetland Resource: Conference Summary. Forest Ecology and Management 33/34: 1-4.

Kantarc1, 1976: Tirakya ormanlarının bölgesel orman yetişme muhiti özelliklerine göre doğal ağaç ve çalı türleriyle sınıflandırılması. İst. Üni. Orman Fak. Der. A/26(2): 138-210.

Kantarcı, M. D. 1979: Kuzey Trakya Dağlık Orman YetişmeBölgesinin YöreselSınıflandırması. İst. Üni. Orman Fak. Der. A/29(2): 42-71.

Kavgac1, A. 2007: Sand-Dune Vegetation of Iğneada Coast in the Thracian Part of Turkey. Hacquetia 6(2): 171-182.

Kavgacı, A., Özalp, G. \& Özhatay, N. 2007: Flora of Igneada floodplain forests (longozes) and their surroundings. İst Üni Orman Fak. Der. A/57(2): 61-90.

Kavgacı, A., Čarni, A., Tecimen, B. \& Özalp, G. 2010: Diversity and Ecological Differantiation of Oak Forests in NW Thrace (Turkey). Archives of Biological Sciences 62(3):705-718.

Kılınç, M. \& Karaer, F. 1995: Sinop yarımadasının vejetasyonu. Turk J Bot 19: 107-124.

Klimo, E. \& Hager, H. (eds.) 2001: The floodplain forests in Europe. Current situation and perspective. Eur. For. Inst. Res. Rep. 10. 268 pp.
Košir, P., Čarni, A. \& Di Pietro, R. 2008: Classification and phytogeographical differentiation of noble hardwood forests in Southeastern Europe. Journal of Vegetation Science 19: 331-342.

Kramer, K., Vreugdenhil, S.J., Stefan, J. \& van der Werf, D.C. 2008: Effect of flooding on recruitment, damage and mortality of riparian tree species: A field and simulation study on the Rhine floodplain. Forest Ecology and Management 255: 3893-3903.

Kutbay, H. G., Kılınç, M. \& Kandemir, A. 1998: Phytosociological and Ecological Structure of Fraxinus angustifolia forests in the Central Black Sea Region. Turk J Bot 22: 157-162.

Lepš, J. \& Šmilauer, P. 2003: Multivariate analysis of ecological data using CANOCO, Cambridge University Press, Cambridge.

Madera, P., Vukelić J., Buček, A. \& Baričević, D. 2008: Floodplain forest plant communities. In: Klimo, E., Hager, H., Matić, S., Anić, I., Kulhavy, J. (eds.) Floodplain forests of the temperate zone of Europe (eds.), Lesnicka prace, s.r.o. Kostelec nad Černymi lesy, p. 102-159.

Magyari, E. K., Chapman, J. C., Gaydarska, B., Marinova, E., Deli, T., Huntly, J. P., Allen, J. R. M. \& Huntley, B. 2008: The 'oriental' component of the Balkan flora: evidence of presence of the Tracian Plain during Weichselian late-glacial. Journal of Biogeography 35(5): 865-883.

Marinček, L. \& Čarni, A. 2000: Die Unterverbände der Hainbuchenwälder des Verbandes Erythronio-Carpinion betuli (Horvat 1938) Marinček in Wallnöfer, Mucina et Grass 1993. Scopolia 45: 1-20.

Mc Cune, B. \& Mefford. M.J. 2006: PG-ORD 5, Multivariate analysis of ecological data. $\mathrm{MjM}$ Sofware Design, Gleneden Beach, Oregon.

Médail, F. \& Diadema, K. 2009: Glacial refugia influence plant diversity patterns in the Mediterranean Basin. Journal of Biogeography 36 : 1333-1345.

Moffatt, S.F. \& McLachlan, S.M. 2004: Understory indicators of disturbance for riparian forests along and urban-rural gradient in Manitoba. Ecological Indicators 4:1-16.

Monica, T., Gergel, S. E., Dixon, M. D. \& Miller, J. R. 2004: Distribution and abundance of trees in floodplain forests of the Wisconsin River: Environmental influences at different scales. Journal of Vegetation Science 15(6) 729-738. 
Müller, N. 1995: River dynamics and floodplain vegetation and their alterations due to human impact. Arch. Hydrobiol. Suppl. 101(3/4): 477-512.

Müller, N. 1998: Effects of natural and human disturbances on floodplain vegetation. In: Müller, N., Okuda, S. \& Tama, N. (eds.): Proceedings of International Symposium for River Restoration, Tokyo, 209 pp.

Özhatay, N., Byfield, A., \&Atay, S. 2003: Türkiye'nin Önemli Bitki Alanları. Doğal Hayatı Koruma Vakfı (WWF Türkiye) yayını, İstanbul.

Paal, J., Rannik, R., Jeletsky, E.M. \& Prieditis, N. 2007: Floodplain forests in Estonia: Typological diversity and growth conditions. Folia Geobotanica 42: 383-400.

Pamay, B. 1967: Demirköy - İğneada longoz ormanlarının silvikültürel analizi ve verimli hale getirilmesi için alınması gereken silvikültürel tedbirler üzerine araştırmalar. Orman Genel Müdürlüğü Yayınları, No. 451/43, İstanbul, 174 pp.

Pavlov, D. \& Dimitrov, M. 2002: A syntaxonomic analysis of the floodplain forests in the maintained reserves "Dolna Topchiya" and "Balabana". Hayka ГОРОТА (Forest Science) 1: 3-19.

Pietsch, S. A., Hasenauer, H., Kučera, J. \& Čermák, J. 2003: Modelling effects of hydrological changes on the carbon and nitrogen balance of oak in floodplains. Tree Physiology 23: $735-746$.

Pignatti, S. 2005: Valori di bioindicazione delle piante vascolari della flora d'Italia. BraunBlanquetia 39: 1-97.

Pivec, J. 2002: A short-term response of floodplain and spruce forests to evaporation requirements in Moravia in different years. Journal of Forest Science 48(7): 320-327.

Quézel, P., Barbéro, M. \& Akman, Y. 1980: Contribution á l'étude de la végétation forestière d'Anatolie septentrionale. Phytocoenologia 8: 365-519.

Raus, T. 1980: Die Vegetation Ostthessaliens (Griechenland). III. Querceo-Fagetea und azonale Gehölzgesellschaften. Bot. Jahrb. Syst. 101(3): 313-361.

Schnitzler, A., Hale, B.W. \& Alsum, E. 2005: Biodiversity of Floodplain forests in Europe and eastern North America: A comparative study of the Rhine and Mississipi Valleys. Biodiversity and Conservation 14: 97-117.

Schuck, A., Parviainen, J. \& Bücking, W. 1994: A review of approaches to forestry research on structure, succession and biodiversity of un- disturbed and semi-natural forests and woodland in Europe. European Forest Institute Working Paper 3, Joensuu, 64 pp.

Sevgi, O. 2005: Soil Characteristics of Different Sites In Stranja (Yildiz) Mountain. In: Chipev, N. (ed.): UESCO-BAS-MOEW Bulgarian Turkish Workshop on Challenges of Establishment and Management of a Trans-Border Biosphere Reserve between Bulgaria and Turkey in Strandzha Mountain, 151 p.

Šilc, U. 2002: Asociacija Salicetum cinereae Zolyomi 1931 v JV Sloveniji. Hacquetia 1(2):165-184.

Šilc, U. 2003: Vegetation of the class Salicetea purpurea in Dolenjska (SE Slovenia). Fitosociologia 40(2): 3-27.

Slavnić, Ž. 1952: Nizinske šume Vojvodine. Zbornik matice srpske 2: 17-38.

Tatarinov, F. \& Čermák, J. 1999: Daily and seasonal variation of stem radius in oak. Ann. For. Sci. 56: 579-590.

Tecimen, H.B. \& Kavgac1, A. 2010: Comparison of soil and forest floor properties of floodplain and surrounding forests in Igneada, Turkey. Journal of Environmental Biology 31: 129-134.

Tepley, A.J., Cohen, J.G. \& Huberty, L. 2004: Natural community abstract for floodplain forest. Michigan Natural Features Inventory, Lansing MI. 14 pp.

Ter Braak, J. F. C. \& Šmilauer, P. 2002: CANOCO Reference Manual and CanoDraw for Windows User's Guide, Software for Canonical Community Ordination (version 4.5), Wageningen.

Thornthwaite, C. W. 1948: An approach toward a rational classification of climate. Geogr. Rev. 38: 55-94.

Tichý, L. 2002: JUICE, software for vegetation classification. Journal of Vegetation Science 13: 451-453.

Tsiripidis, I., Bergmeier, E. \& Dimopoulos, P. 2007: Geographical and ecological differentiation in Greek Fagus forest vegetation. Journal of Vegetation Science 18: 743-750.

Tockner, K., \& Standford, J.A. 2002: Riverine flood plains: present state and future trends. Environmental Conservation 29: 308-330.

Turner, M.G., Gergel, S. E., Dixon, M.D. \& Miller, J.R. 2004: Distribution and abundance of trees in floodplain forests of the Wisconsin River: Environmental influences at different scaled. Journal of Vegetation Science 15: 729-738.

Türe, C., Tokur, S., \& Ketenoglu, O. 2005: Contribution to the syntaxonomy and ecology of the 
forest and shrub vegetation in Bithynia, Northwestern Antolia, Turkey. Phyton (Austria) 45 (1): 81-115.

Tzonev, R., Dimitrov, M., Chytrý, M., Roussakova, V., Dimove, D., Gussev, C., Pavlov, D., Vulchev, V., Vitkova, A., Gogoushev, G., Nikolov, I., Borisova, D. \& Ganeva, A. 2006: Beech Forest communities in Bulgaria. Phytocoenologia 36(2): 247-279.

Vukelić, J. \& Baričević, D. 2004: The association of spreading elm and narrow-leave ash (Fraxino-Ulmetum effusae Slav. 1952) in floodplain forest of Podravina and Podunavlje. Hacquetia 3: 49-60.

Vukelić J, Baričevič D 2005: Šumska vegetacija poplavnih područja. In: Vukelić, J., Prpić, B., Kajba, B., Matić, S., Vratarić, P., Glavaš, M. \& Jakovac, H. (eds.): Poplavne šume u Hrvatskoj. Akademija šumarskih znanosti, Zagreb.

Wallnöfer, S. 2009: A new Alnion incanae association of the Inner Italian Alps: Hedero helicisAlnetum glutinosae. Phyton (Austria) 49: 9-23.

Weber, H.E., Moravec, J. \& Theurillat, J. P. 2000: International code of phytosociological nomenclature. 3rd edition. Journal of Vegetation Science 11: 739-768.

Wenger, E.L., Zinke, A. \& Gutzweiler, K.A. 1990: Present situation of the European floodplain forests. Forest Ecology and Management 33/ 34: 5-12.

Westhoff, V. \& van der Maarel, E. 1973: The Braun-Blanquet approach. In: Whittaker, R. H. (ed.): Handbook of Vegetation Science 5, Ordination and classification of communities, Junk, The Hague, pp. 617-726.

Wildi, O. 1989: Analysis of the disintegrating group and gradient structure in Swiss riparian forests. Vegetatio 83: 179-186.

Willner, W. 2007: Carpinion betuli Issler 1931. In: Willner, W. \& Grabherr, G. (eds.): Die Wälder und Gebüsche Österreichs. Elsevier Verlag. München, 137-144.

Yaltırık, F., Akman, Y. \& Ketenoğlu, O. 1983: A phytosociological research in the Belgrad forest. Comm Fac Sci Univ C(1): 1-9.

Zelnik, I. \& Čarni, A. 2008: Wet meadows of the alliance Molinion and their environmental gradients in Slovenia. Biologia 63: 187-196.

Zoller, H., Geissler P. \& Athanasiadis, N. 1977: Beiträge zur Kenntnis der Wälder, Moos- und Flechtenassoziationen in den Gebirgen Nordgriechenlands. Bauhinia 6 (1): 215-255.

\section{APPENDIX}

Field characteristics of the relevés and coverage of the layers in Table 1 and given in the following order: consecutive number, upper tree layer (\%), lower tree layer (\%), scrub layer (\%), herb layer (\%), altitude (m), aspect, inclination (\%), latitude and longitude.

1) $50 ; 50 ; 70 ; 30 ; 10 ; \mathrm{NE} ; 2 ; 580221 ; 4629825$ - 2) $100 ; 10 ; 5$ 80; 5 ; NE; 2 ; 581510; 4630355 - 3) 100; 70; 40; 70; 10; NE; 2; $580955 ; 4629764$ - 4) $80 ; 80 ; 50 ; 70 ; 5 ; \mathrm{N} ; 1 ; 581455 ; 4629562$ - 5) $50 ; 70 ; 50 ; 80 ; 10 ; \mathrm{NE} ; 4 ; 581161 ; 4629060$ - 6) 100; 50; 5; 100; 10; E; 2; 580256; 4629265 - 7) 90; 70; 20; 80; 10; SE; 2; $580783 ; 4628719$ - 8) 100; 70; 10; 80; 5; E; 2; 581815; 4628836 - 9) 90;70; 70; 90; 4; NE; $1 ; 581958 ; 4628809$ - 10) 50; 20; $80 ; 30 ; 10 ; \mathrm{E} ; 3 ; 580535 ; 4630051$ - 11) $100 ;$; 50; 60; 3; S; 2 ; 581080; 4630370 - 12) $80 ; 50 ; 15 ; 80 ; 10 ; \mathrm{NE} ; 2 ; 580421$; 4629788 - 13) $80 ; 20 ; 60 ; 70 ; 30 ; \mathrm{N} ; 4 ; 580399 ; 4630635$ - 14) $70 ; 30 ; 50 ; 50 ; 25 ; \mathrm{N} ; 2 ; 578822 ; 4630711$ - 15) 70; 20; 90; 50; 15; $\mathrm{NE} ; 1 ; 580653 ; 4630610$ - 16) 70; 80; 60; 90; 10; E; 1; 579667; 4629748 - 17) $70 ; 40 ; 60 ; 80 ; 10 ; \mathrm{E} ; 1 ; 580311 ; 4629786$ - 18) 80; 70; 50; 50; 10; E; $1 ; 580744 ; 4629875$ - 19) 100; 5; 1; 100; 3; NE; $2 ; 581839 ; 4630030$ - 20) 100; 20; 10; 80; 3; E; 2; 582363; 4628747 - 21) $100 ; 20 ; 20 ; 90 ; 2$; NE; $1 ; 582400 ; 4628648$ - 22) 80; 60; 70; 50; 5; E; 1; 579224; 4634994 - 23) 70; 70; 80; 50; 5; E; 1; 579632; 4635272 - 24) 100; 30; 1; 90; 5; E; 1; 579961; 4635639 - 25) 100; 70; 20; 70; 10; E; 3; 577889; 4635763 - 26) $60 ; 70 ; 90 ; 10 ; 10 ; \mathrm{E} ; 1 ; 578436 ; 4636308$ - 27) 90; 70; 5; 80; 15; E; $1 ; 578924 ; 4636399$ - 28) 100; 80; 60; 20; 4; E; 1; 581059; 4633394 - 29) $100 ; 10 ; 1 ; 70 ; 5 ; \mathrm{E} ; 1 ; 580196 ; 4636255$ - 30) 90; 20; 30; 90; 4; E; 1; 582017; 4638342 - 31) 80; 50; 70; 30; 5; SE; $2 ; 582275 ; 4638766$ - 32) 90; 70; 3; 80; 4; NE; 1; 582013; 4629309 - 33) $100 ; 20 ; 50 ; 50 ; 5 ; \mathrm{E} ; 1 ; 579660 ; 4635732$ - 34) $50 ; 60 ; 80 ; 80 ; 5 ; \mathrm{E} ; 1 ; 579196 ; 4635167$ - 35) 60; 60; 60; 70; 5; E; 1; 579376; 4635763 - 36) 80; 70; 30; 70; 5; E; 1; 578941; 4636077 - 37) 80; 60; 50; 50; 5; E; $1 ; 578485 ; 4635963$ - 38) 90; 30; 90; 40; 5; E; 1; 578619; 4635496 - 39) 90; 20; 100; 40; 5; E; $1 ; 578117 ; 4635487$ - 40) 90; 70; 60; 70; 10; E; 1; 577347; 4635674 - 41) $50 ; 80 ; 90 ; 50 ; 5$; SE; 1 ; 581751; 4638824 - 42) 80; 50; 40; 30; 5; SE; 1; 581420; 4639003 - 43) 80; 90; 70; 50; 5; E; $1 ; 581033 ; 4639071$ - 44) 80; 80; 80; 20; 5; SE; $1 ; 580627$; 4639433 - 45) 100; 10; 60; 30; 15; E; 1 ; 578467; 4640241 - 46) 100; 50; 40; 80; 10; E; 1; 578894; 4639979 - 47) 70; 50; 90; 20; 10; E; $1 ; 579382 ; 4639679$ - 48) 70; 70; 80; 5; 10; SE; $1 ; 580059$; 4640236 - 49) 100; 30; 70; 50; 10; E; 1 ; 580580; 4639875 - 50) 100; 30; 50; 40; 5; E; 1; 580034; 4639315 - 51) 95; 30; 60; 20; 20; NE; 8; 581218; 4627586 - 52) 100; 20; 90; 20; 20; SE; 8; 580600; 4628047 - 53) 90; 80; 10; 20; 25; NW; 15; 579889; 4631728 - 54) 100; 30; 70; 50; 30; W; 7; 579090; 4631694 - 55) 100; 40; 30; 70; 20; NE; 8; 580526; 4632533 - 56) 90; 30; 70; 20; 5 ; NE; $3 ; 581120 ; 4632498$ - 57) 100; 40; 60; 20; 10; NE; $10 ; 581455 ; 4631169$ - 58) $100 ; 40 ; 40 ; 30 ; 55 ; \mathrm{N} ; 8 ; 578944$; 4632658 - 59) $80 ; 70 ; 2 ; 80 ; 25 ; \mathrm{E} ; 5 ; 577441 ; 4635203$ - 60) $100 ; 70 ; 10 ; 50 ; 40 ; \mathrm{NW} ; 2 ; 579011 ; 4633191$ - 61) $90 ; 100$; 20; 60; 25; NE; 2; 579671; 4633062 - 62) 90; 40; 20; 30; 20; $\mathrm{N} ; 2 ; 579092 ; 4633858$ - 63) 90; 20; 70; 50; 5; NE; 1; 579927; 4634357 - 64) $100 ; 50 ; 90 ; 10 ; 15 ; \mathrm{N} ; 15 ; 578903 ; 4635007$ - 65) 100; 40; 70; 20; 25; N; 17; 578310; 4635304-66) 100; 40; 70; $40 ; 25 ; \mathrm{N} ; 6$; 582397; 4627369 - 67) 100; 30; 70; 60; 20; N; 1 ; $581289 ; 4628059$ - 68) $100 ; 60 ; 50 ; 60 ; 15 ; \mathrm{NE} ; 25 ; 577496$; 4631475 - 69) 80; 60; 60; 60; 60; E; 1; 578269; 4633832. 
Table 1: Vegetation table of the relevés. The relevés are ordered according to the cluster analysis presented in Figure 2; group numbers correspond to the community numbers mentioned the same figure. Legend: upper tree layer (t1), lower tree layer (t2), scrub layer (s) and herb layer (h). Coverage of the layers and localities of the relevés are submitted in the appendix. ${ }^{*}$ indicates holotypes.

Group number

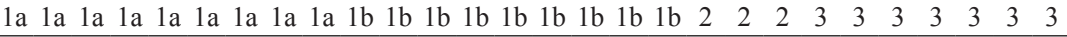

Running number

$\begin{array}{llllllllllllllllllllllllllll}1 & 2 & 3 & 4 & 5 & 6 & 7 & 8 & 9 & 10 * & 11 & 12 & 13 & 14 & 15 & 16 & 17 & 18 & 19 & 20 & 21 & 22 & 23 & 24 & 25 & 26 & 27 & 28\end{array}$

Diagnostic species

Ulmus laevis

Ulmus laevis

Ulmus laevis

Ulmus laevis

Juglans regia

Juglans regia

Juglans regia

Phytolacca americana

Acer trautvetteri

Acer trautvetteri

Sambucus nigra

Parietaria officinalis

Chaerophyllum temulum

Lysimachia vulgaris

Iris pseudacorus

Polygonum lapathifolium

Leucojum aestivum

Galium debile

Alnus glutinosa

Alnus glutinosa

Fraxinus angustifolia

Fraxinus angustifolia

Fraxinus angustifolia

Fraxinus angustifolia

Ulmus minor

Ulmus minor

Ulmus minor

Ulmus minor

Ranunculus repens

Lysimachia nummularia

Veronica serpyllifolia

Acer campestre

Acer campestre

Acer campestre

Acer campestre

Mercurialis perennis

Carpinus betulus

Carpinus betulus

Carpinus betulus

Carpinus betulus

Geranium robertianum

Polygonatum latifolium

Epimedium pubigerum

Tilia argentea

Tilia argentea

Tilia argentea

Tilia argentea

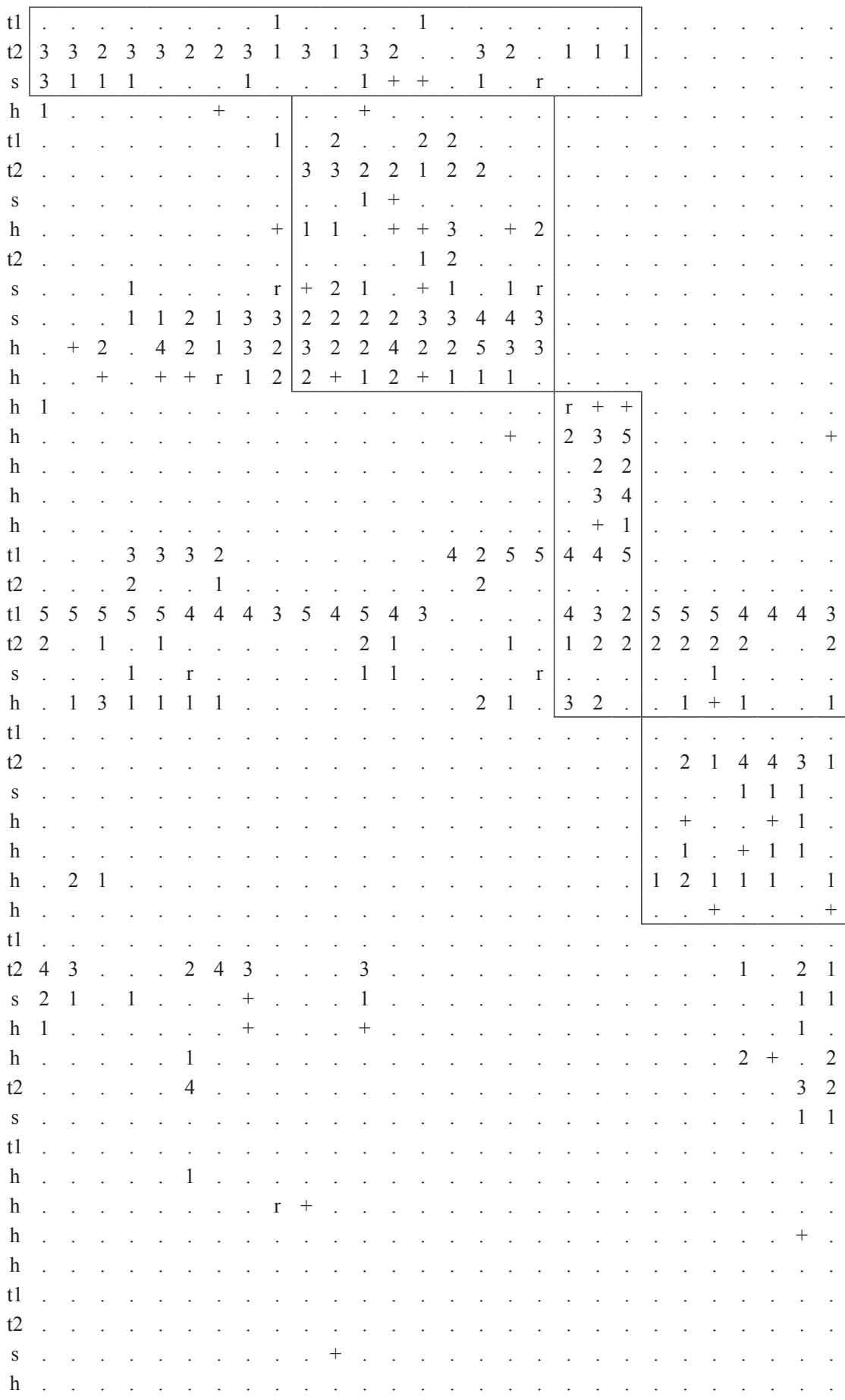


Tabela 1: Vegetacijska tabela. Popisi so razporejeni kot v klastrski analizi prikazani na Sliki 2; številke skupin se nanašajo na številke skupin na isti sliki. Legenda: zgornja drevesna plast (t1), spodnja drevesna plast (t2), grmovna plast (s) and zeliščna plast (h). Pokrovnost plasti in lokacije popisov so prikazane v dodatku. ${ }^{\star}$ nakazuje holotipe.

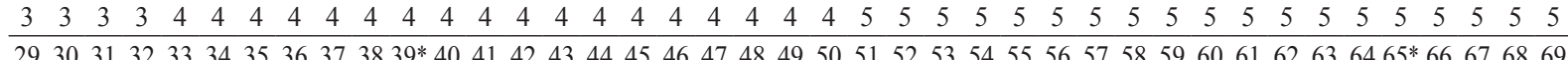

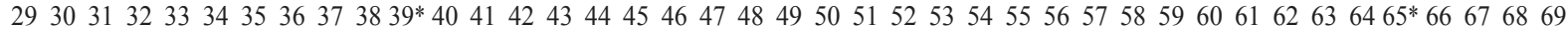

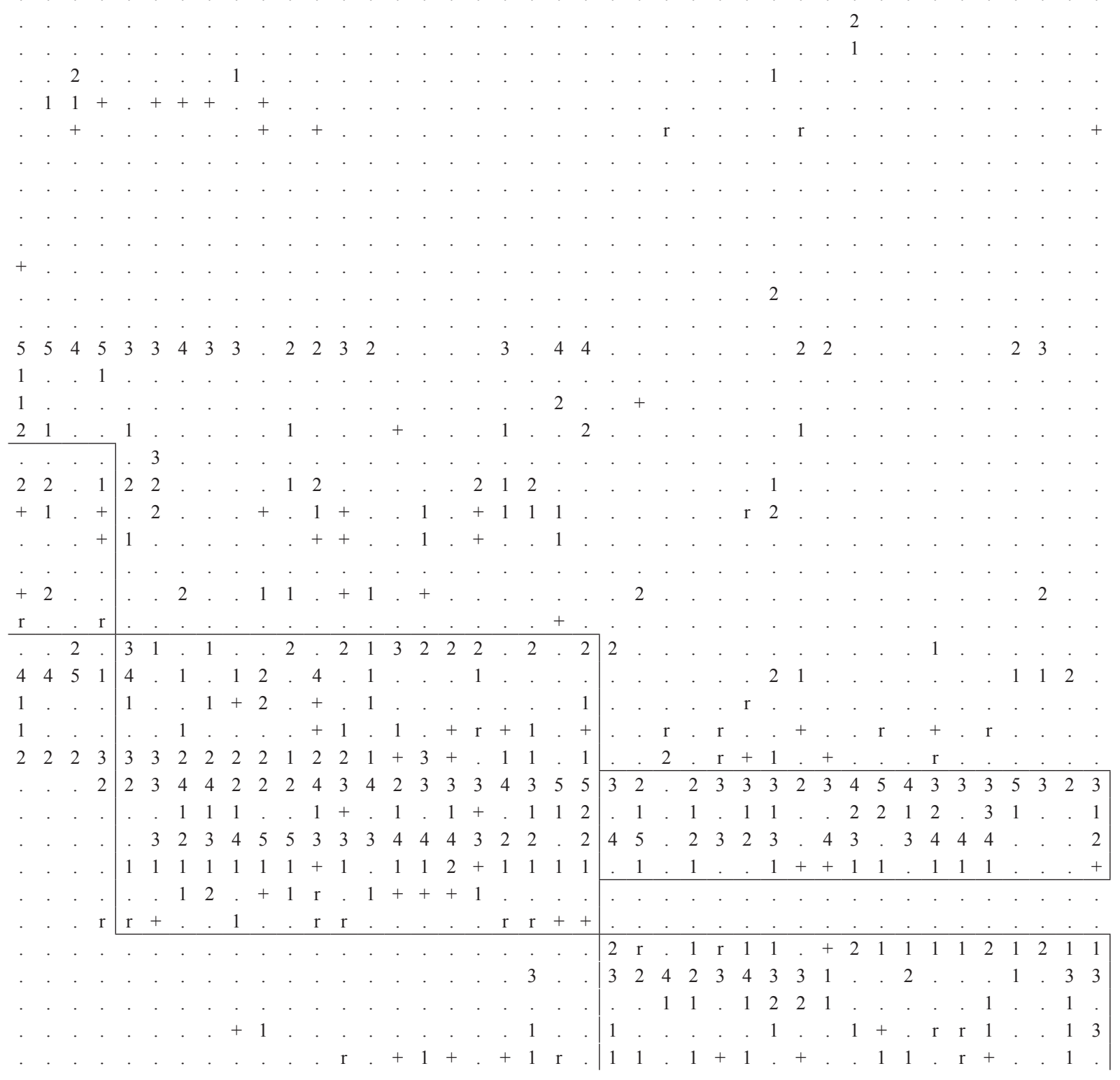


Primula vulgaris h

Fragaria vesca

Quercus petraea

Quercus petraea

Quercus petraea

Quercus petraea

Lathyrus laxiflorus

Fagus orientalis

Fagus orientalis

Fagus orientalis

Fagus orientalis

Galium paschale

Populus tremula

Populus tremula

Populus tremula

Populus tremula

Trachystemon orientalis

Veronica chamaedrys

Pteridium aquilinum

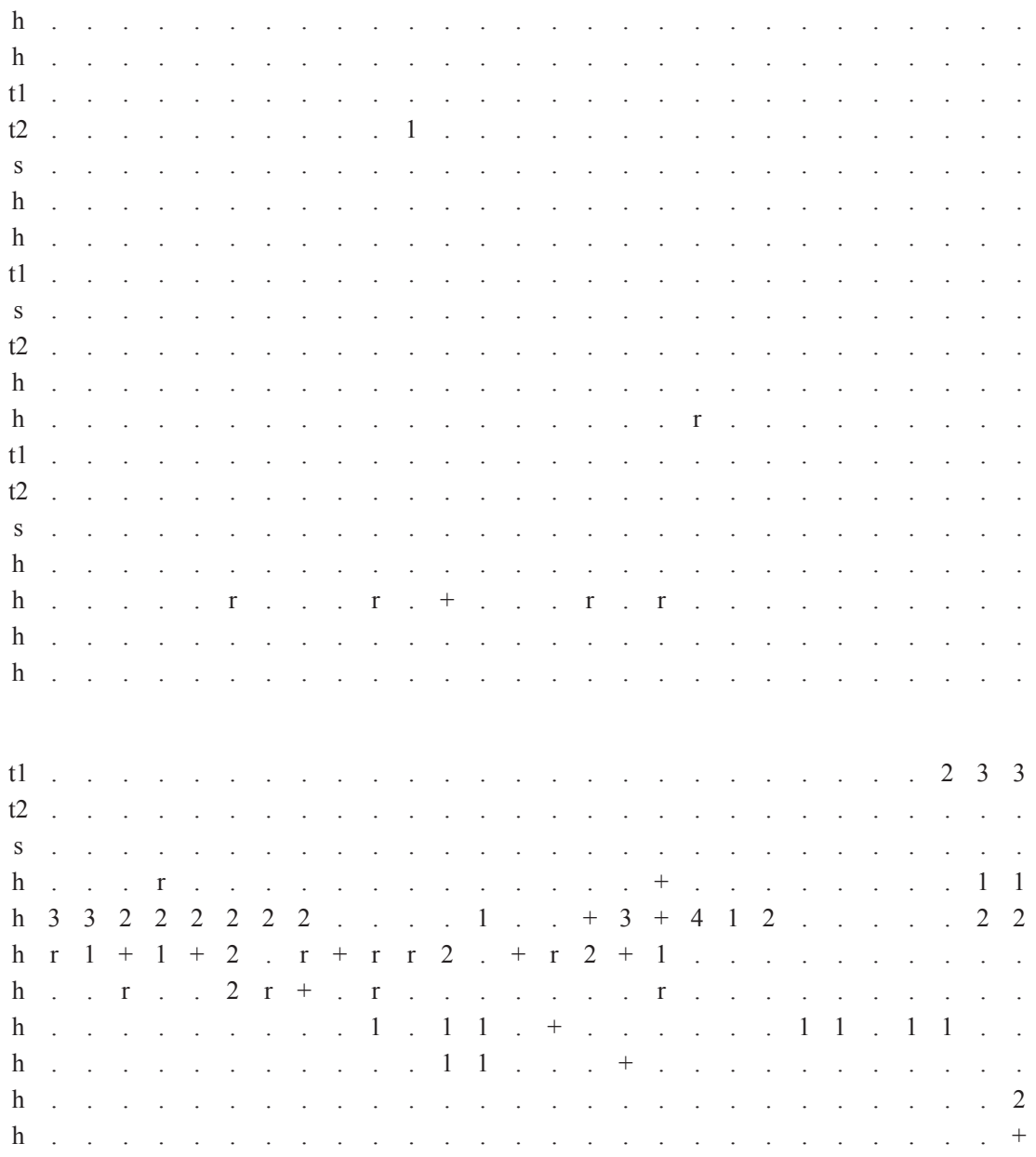

\section{ALNO-QUERCION}

Quercus robur

Quercus robur

Quercus robur

Quercus robur

Carex remota

Circaea lutetiana

Alliaria petiolata

Carex divulsa

Galium aparine

Festuca gigantea

Cruciata laevipes

\section{POPULETALIA ALBAE}

Populus alba

Populus alba

Rubus caesius

Rumex conglomeratus

Urtica dioica

Cornus sanguinea

Oenanthe silaifolia

Melissa officinalis

Glechoma hederacea

Humulus lupulus

Lycopus europaeus

Potentilla reptans

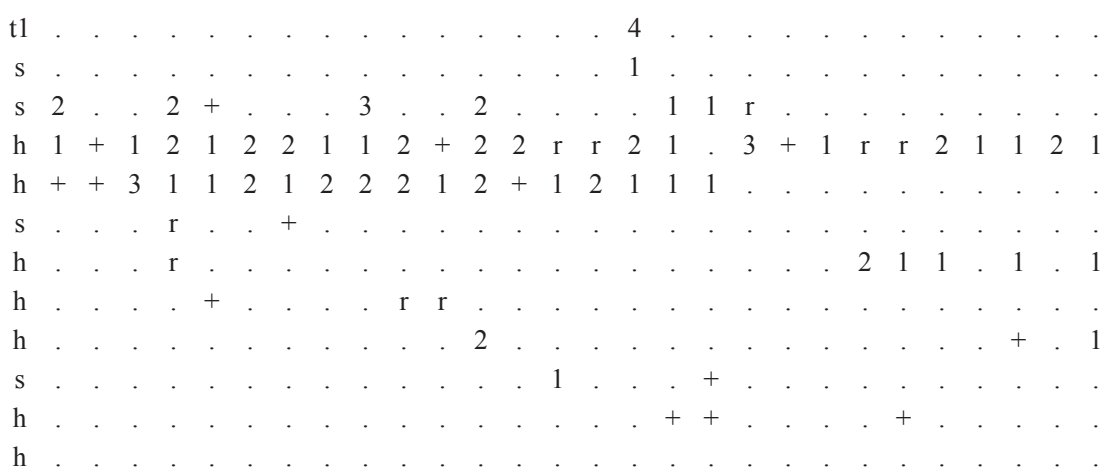

\section{CASTANEO-CARPINION AND RHODODENDRO-FAGETALIA}

Smilax excelsa

Daphne pontica

Salvia forskahlei

Sambucus ebulus

Ruscus hypoglossum

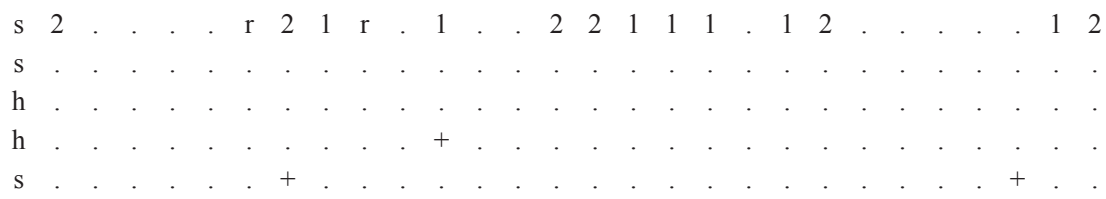

QUERCO-FAGETEA

Crataegus monogyna

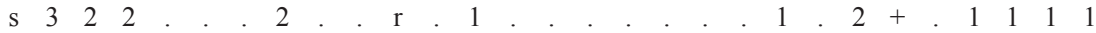




\begin{tabular}{|c|c|c|c|c|c|c|c|c|c|c|c|c|c|c|c|c|c|c|c|c|c|c|c|c|c|c|c|c|c|c|c|c|c|c|c|c|c|c|c|}
\hline & & & & & & & & & & & & & & & & & & & & & & & & & & & & & & & & & & & & & & & \\
\hline & & . & & . & . & & . & & & . & & & & & & & & & & & 1 & & & & & & & & & & & & & & & & & & \\
\hline & . & & . & 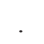 & . & & . & . & & . & & & & & & & & & & & & & & & & & & & & & & & & & & & & & \\
\hline & . & . & . & . & . & & 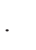 & . & & . & & & & & & & & & & & & & & & & & & & & & & & & & & & & & \\
\hline & . & & & & & & & & & & & & & & & & & & & & & & & & & & & & & & & & & & & & & & \\
\hline & . & . & . & . & . & . & . & . & & . & & . & . & . & & & . & & . & & & & & & & & & & & & & & & & & & & & \\
\hline & . & . & . & . & . & . & 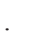 & . & & . & & & & & & & & & & & & & & & & & & & . & & & & & & 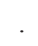 & & & & \\
\hline & . & & & . & . & & 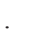 & . & & . & & & . & & & & & & & & & & 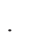 & & & & & & & & & & & & & & & & \\
\hline & . . & . & . & . & . & & . & . & & . & & & & & & & & & & & & & & & 2 & 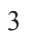 & & & & & . & & 2 & & & & & & \\
\hline & . & . & & . & . & & . & . & & . & & & $\cdot$ & . & & & . & & & & & & & & & 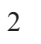 & & & . & & $\mathrm{r}$ & & & & & & & & \\
\hline & . & . & . & . & . & . & . & . & . & 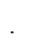 & & . & . & & . & & . & & & & & & & & & . & & & & . & 1 & & 1 & & & & & & \\
\hline & . . & . & . & . & . & . & . & . & & 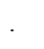 & & & $\cdot$ & & & & & & & & & & & & & . & & & 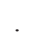 & & $\cdot$ & & & & & & & & \\
\hline & . & - & . & . & . & . & . & . & & . & & & & & & & & & & & & & & & & $\cdot$ & + & + & + & + & + & & $\mathrm{r}$ & & & & + & + & \\
\hline & . . & . & . & . & . & . & . & . & . & . & $\cdot$ & 2 & . & . & $\cdot$ & & . & & - & . & 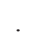 & & & . & & . & 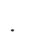 & · & . & 4 & 5 & & 1 & & 2 & & $\cdot$ & & \\
\hline & . & . & . & . & . & . & . & . & . & . & & . & . & & & & & & & & & & & & & . & & & $\cdot$ & & & & & & & & & & \\
\hline & . & . & . & . & . & . & . & . & . & . & & . & . & & . & & . & 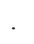 & + & . & . & & & . & & $\mathrm{r}$ & & 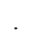 & $\cdot$ & & $\cdot$ & & $\cdot$ & & 3 & + & 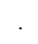 & 1 & \\
\hline & . & . & . & . & . & . & . & . & . & . & & & & & & & & & & & & & & 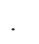 & & ${ }^{\circ}$ & & & . & & . & & 1 & 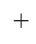 & + & & & & \\
\hline & . & . & . & . & . & + & . & . & & . & & 1 & 1 & $\cdot$ & + & & r. & & & . & 2 & & & 2 & 2 & 2 & & & 1 & & 1 & & 1 & 2 & & & & 3 & \\
\hline & ${ }^{\circ}$ & . & r & . & . & & $\cdot$ & . & . & . & & & & & & & & & & & & & & . & & . & & & & & & & & & 1 & & $r$ & & \\
\hline & & & & . & & & 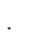 & & & . & & & & & & & & & & & & & & & & & & & & & $\mathrm{r}$ & & & & & & & $\mathrm{r}$ & \\
\hline
\end{tabular}

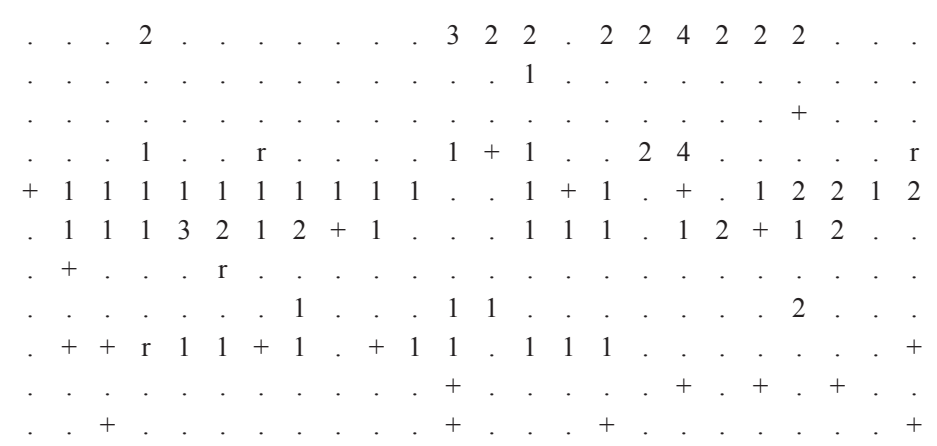

$\begin{array}{lllllllllllllllllllllllll}1 & 3 & 1 & 1 & 2 & 1 & 1 & 1 & . & 1 & 1 & 1 & 2 & 2 & + & 1 & & \mathrm{r} & \mathrm{r} & . & + & + & +\end{array}$

$31+122+r \quad 1 \quad r . r$.

$\mathrm{r} . .5 . \quad . \quad . \quad \mathrm{r} 2$

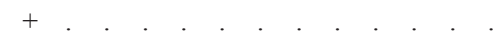

$\begin{array}{lllllllllllllllllllllllllllllllllllllllllllllllllll}3 & 1 & 1 & \mathrm{r} & 2 & 2 & 1 & 2 & 2 & 2 & 1 & 1 & 2 & 2 & 2 & 1 & 1 & 2 & 3 & 2 & 2 & 3 & 1 & 2 & \cdot & 1 & 1 & 2 & . & 2 & 4 & 2 & 2 & + & 2 & 3 & 1 & + & 1 & 1 & \mathrm{r}\end{array}$

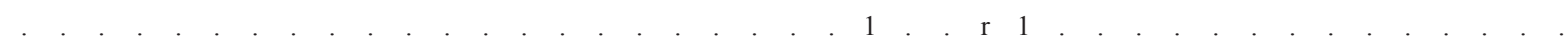

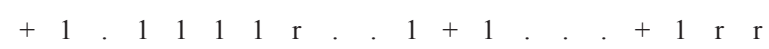


Rosa canina

Carex sylvatica

Viola alba

Viola sieheana

Rubus hirtus

Corylus avellana

Corylus avellana

Hedera helix

Ruscus aculeatus

Cornus mas

Euonymus europaeus

Mespilus germanica

Brachypodium sylvaticum

Mycelis muralis

Symphytum tuberosum

Tamus communis

Sanicula europaea

Ajuga reptans

Ligustrum vulgare

Sorbus torminalis

Sorbus torminalis

Sorbus torminalis

Sorbus torminalis

Prunus domestica

Poa nemoralis

Quercus cerris

Quercus cerris

Vincetoxicum hirundinaria

Rubus canescens

Fritillaria pontica

Stellaria holostea

Festuca drymeia

Platanthera bifolia

Hypericum perforatum

Carpinus orientalis

Carpinus orientalis

Campanula persicifolia

Quercus frainetto

Quercus frainetto

Carex flacca

Luzula forsteri

Fraxinus ornus subsp. ornus

Fraxinus ornus subsp. ornus

Fraxinus ornus subsp. ornus

Sorbus domestica

Hypericum bitynicum

Euphorbia amygdaloides

Ajuga laxmannii

Brachypodium pinnatum

Stachys thirkei

Digitalis ferruginea

Lychnis coronaria

Cyclamen coum

Anthemis tinctoria subsp. tinctoria

Genista tinctoria

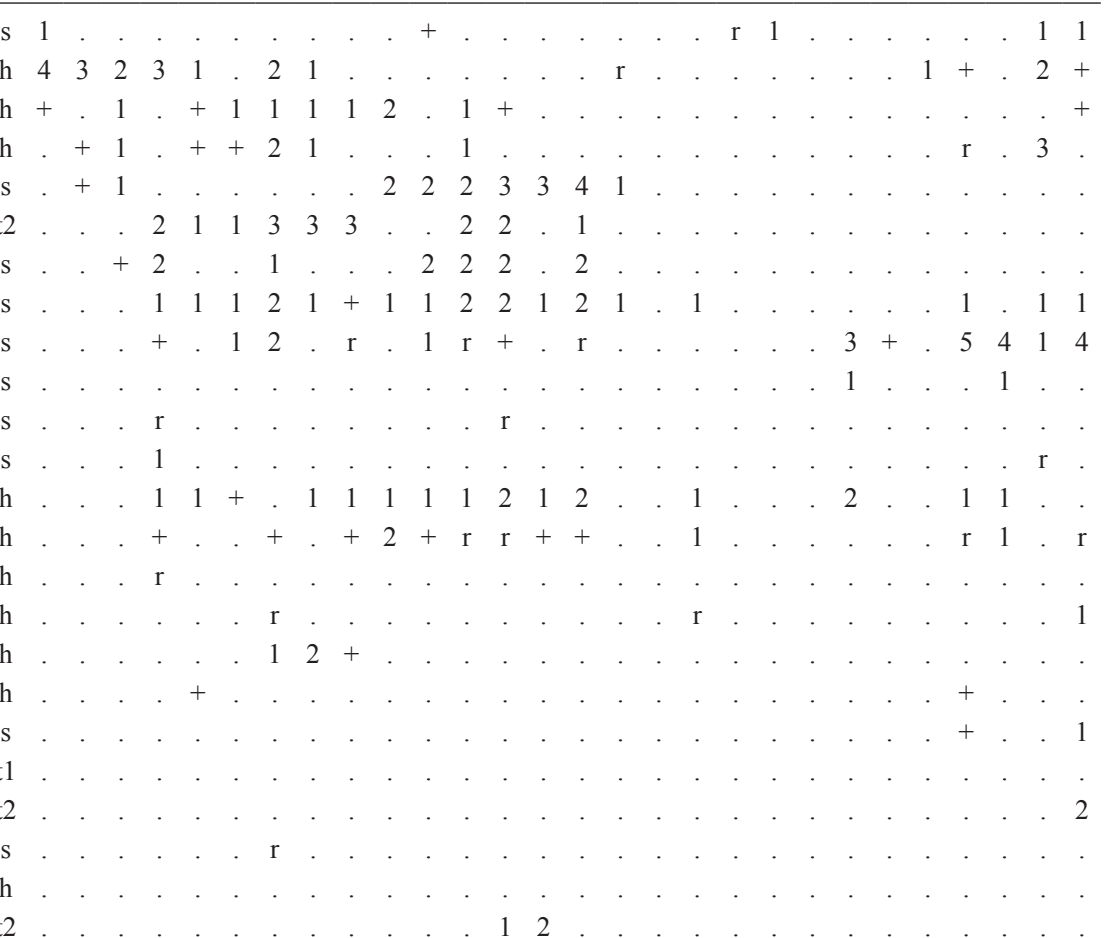

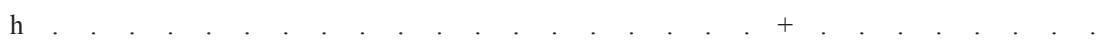

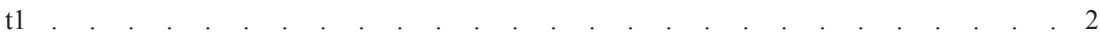

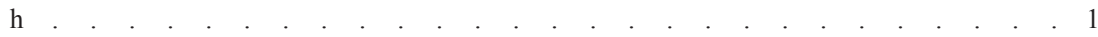

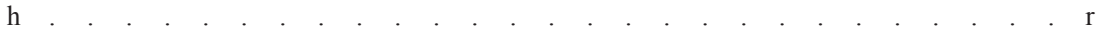

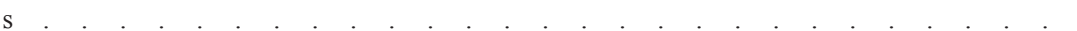

h

h

h

h

t1

t2

h

$\mathrm{S}$

t2

t2

h

h

h

h

h

h

h

h

h 


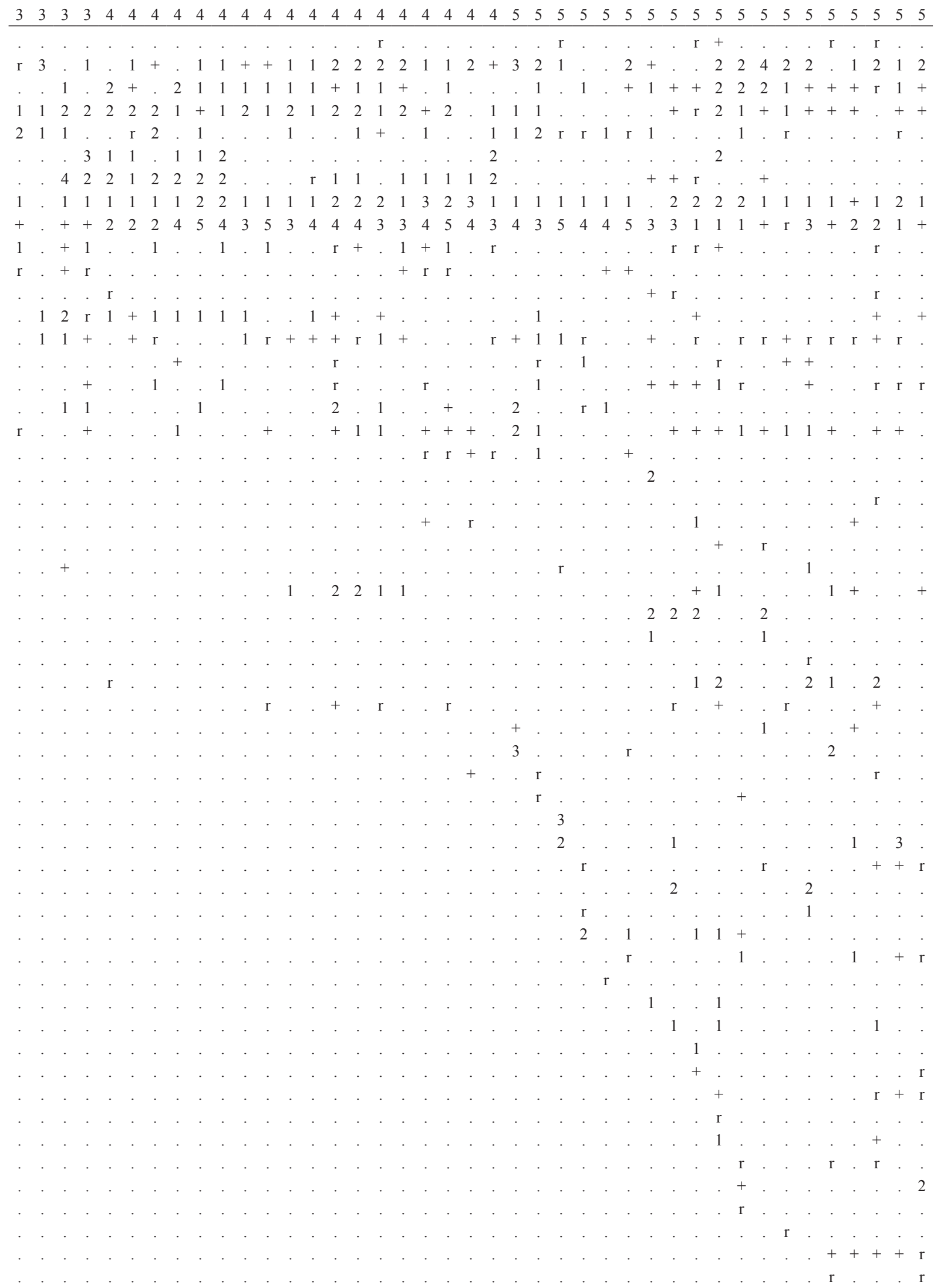


Sorbus domestica

Centaurea stenolepis

Carpinus orientalis

Carpinus orientalis

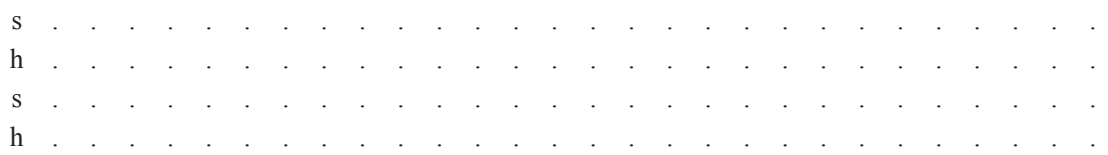

\section{Others}

Geum urbanum

Dactylis glomerata

Lamium maculatum

Poa trivialis

Prunella vulgaris

Euphorbia stricta

Ranunculus constantinapolitanus

Melica uniflora

Aegopodium podagraria

Veronica montana

Polygonum hydropiper

Pulmonaria obscura

Orobanche caryophyllacea

Arum italicum

Arctium minus

Prunus domestica

Trifolium hybridum subsp. hybridum

Moehringia trinervia

Juncus effusus

Geranium lucidum

Aethusa cynapium

Petasites hybridus

Vitis vinifera subsp. sylvestris

Deschampsia cespitosa

Cirsium vulgare

Ornithagalum sphaeracarpum

Senecio aquaticus

Listera ovata

Dryopteris filix-mas

Milium effusum

Polystichum setiferum

Lamium species

Cephalanthera damasonium

Scutellaria albida

Veronica officinalis

Holcus lanatus

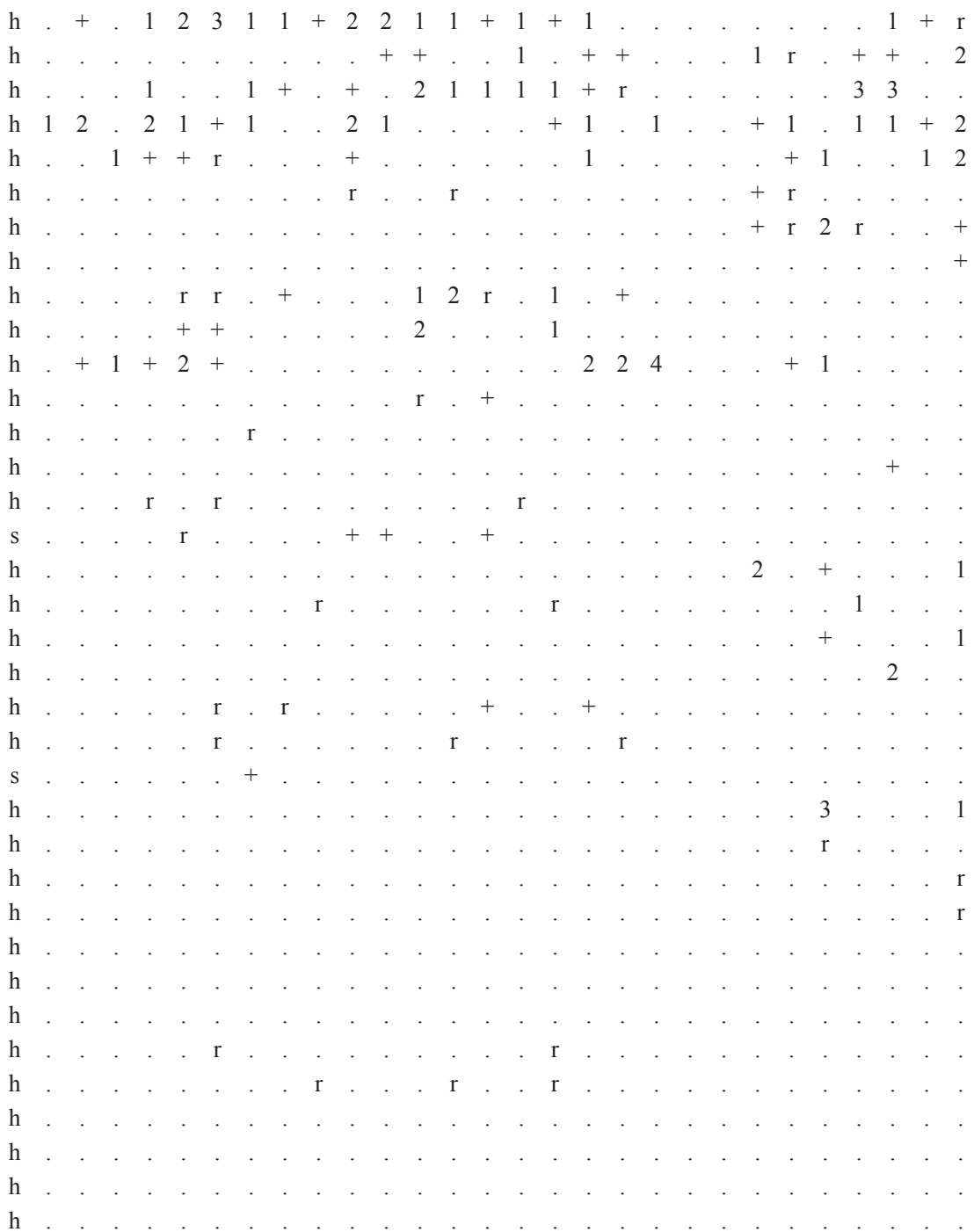

Species with low frequencies

Salix alba [t2] 7: 1, 17: 1; Mentha aquatica [h] 11: 1, 17: +; Clematis vitalba [s] 13:2, 14: 1; Myrrhoides nodosa [h] 14: +, 31: +; Eupatorium cannabinum $[\mathrm{h}]$ 14: $\mathrm{r}, 18: 1$; Myosotis laxa $[\mathrm{h}]$ 17:1,29: +; Equisetum arvense $[\mathrm{h}]$ 18: $\mathrm{r}, 60: 1$; Lolium perenne $[\mathrm{h}] 22$ : 4, 24: 1; Poa annua [h] 23: 5, 24: 2; Cardamine uliginosa [h] 29: +, 50: 1; Galega officinalis [s] 29: r, 58: r; Scrophularia scopolii [h] 30: r, 36: r; Allium paniculatum [h] 45: r, 65: r; Lysimachia punctata [h] 52: r, 67: r; Lathyrus niger [h] 54: r, 67: r; Centaurium erythraea $[\mathrm{h}]$ 59: $\mathrm{r}, 67:+$; Lathyrus venetus $[\mathrm{h}]$ 62: 1, 65: r; Festuca heterophylla $[\mathrm{h}]$ 67: +, 68: +; Tanacetum parthenium $[\mathrm{h}] 3: \mathrm{r}$; Physalis alkekengi [h] 4: +; Anchusa officinalis [h] 15: r; Scutellaria galericulata [h] 17: 1; Stellaria media [h] 18: r; Cynosurus cristatus [h] 22: 3; Agrostis stolonifera [h] 22: 3; Bellis perennis [h] 22: 2; Bromus hordeaceus $[\mathrm{h}]$ 22: 1; Hordeum geniculatum [h] 22: +; Polygonum aviculare $[\mathrm{h}]$ 23: 2; Trifolium repens var. macrorhizum $[\mathrm{h}]$ 23: +; Trifolium micranthum $[\mathrm{h}]$ 23: +; Myosotis alpestris [h] 24: 1; Alisma lanceolatum [h] 24: 1; Juncus bufonius [h] 24: 1; Trifolium resupinatum var. resupinatum [h] 24: +; Anthemis cotula [h] 24: +; Plantago major [h] 30: $\mathrm{r}$; Chaerophyllum byzantium [h] 31: +; Chelidonium majus [h] 31: r; Limodorum abortivum [h] 43: r; Nectorascordum siculum [h] 50: r; Asparagus acutifolius [h] 58: r; Linaria genistifolia [h] 61: +; Luzula multiflora $[\mathrm{h}]$ 67: +; Tanacetum corymbosum $[\mathrm{h}]$ 67: r; Dorycnium graecum $[\mathrm{h}]$ 69: r. 


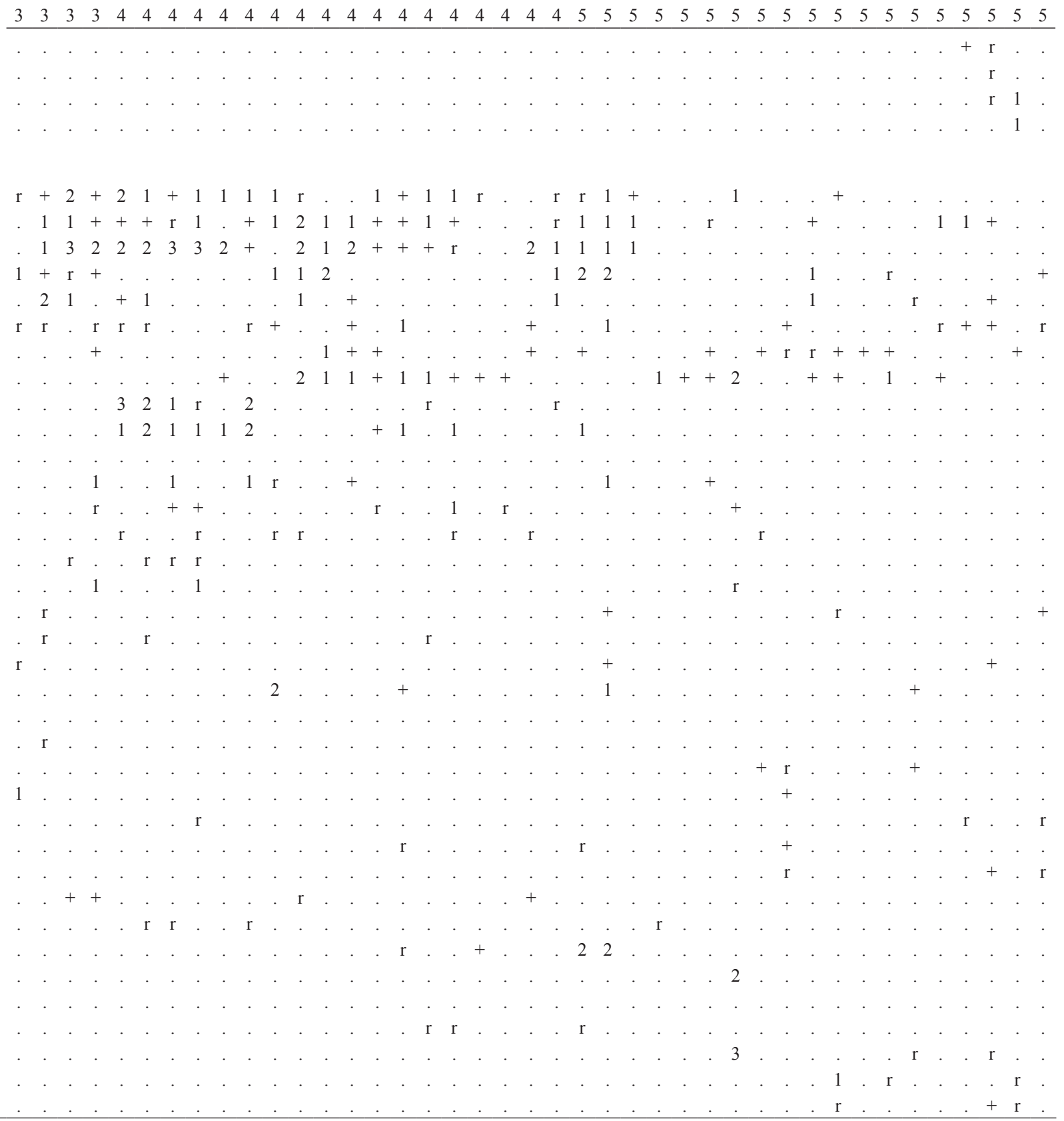

Received 12.3.2010

Revision received 23.11.2010

Accepted 2.2.2011 